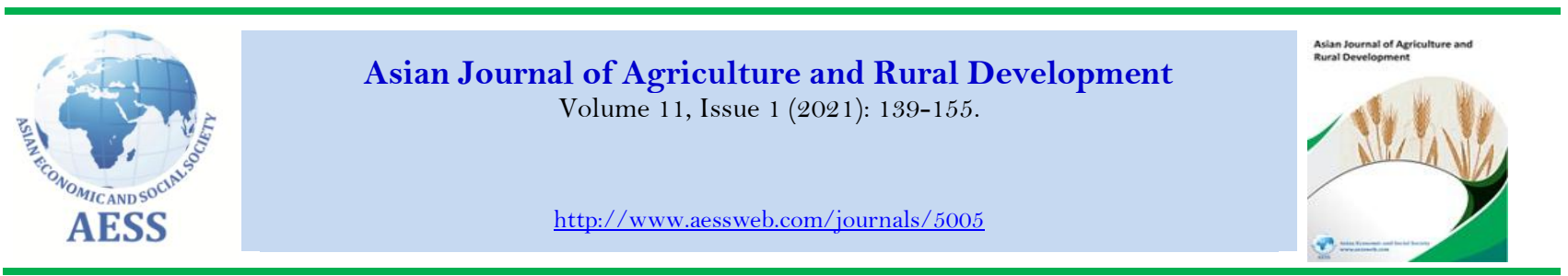

\title{
INFLUENCE OF SHORT-TERM MAIZE-GREEN MANURE COVER CROP ROTATIONS ON GERMINABLE WEED SEED BANK UNDER CONSERVATION AGRICULTURE
}

\author{
Rugare Joyful Tatenda ${ }^{a}$ \\ Pieterse Petrus Jacobus ${ }^{b}$ \\ Mabasa Stanford ${ }^{c}$
}

\author{
a.Department of Agronomy, Stellenbosch University, South Africa, South Africa; \\ Department of Crop Science, University of Zimbabwe, Mount Pleasant, Harare, \\ Zimbabwe. \\ ${ }^{b}$ Department of Agronomy, Stellenbosch University, South Africa, Private Bag X1 \\ Matieland, South Africa. \\ Department of Crop Science, University of Zimbabwe, Mount Pleasant, Harare, \\ Zimbabwe.
}

- rugarejoy@yahoo.co.uk (Corresponding author)

\section{Article History}

Received: 4 May 2020

Revised: 26 February 2021

Accepted: 15 March 2021

Published: 6 April 2021

\section{Keywords}

Allelopathy

Conservation agriculture

Crop rotation

Cover crops

Weed seed bank

Zea mays $\mathrm{L}$.

\begin{abstract}
The effects of one- and two-year maize-cover crop rotations on weed seed bank density and species composition were evaluated in fields at the University of Zimbabwe (UZ) and the International Maize and Wheat Improvement Center (CIMMYT, Harare) between 2014 and 2017. Nine cover crops were rotated, and maize and weed seed bank analyses were done using the seedling emergence method. Maize was used as the control. The results indicated that weed seed density was not significantly $(p>0.05)$ affected by cover crop mulch type across the seasons. There was a significant $(p<0.05)$ decline in weed density in the second maize phase of the rotation in UZ Field A. Bidens pilosa, Galinsoga parviflora, Amaranthus hybridus and Eleusine indica were the dominant weeds. B. pilosa density significantly decreased in the second season in UZ Field A but did not vary significantly among cover crops. Significant changes in weed species richness, evenness, and diversity were observed only in the second phase of the rotation in UZ Field A. The results suggest that maize-cover crop rotations could be effective in reducing seed bank size in the short term but have no short-term effect on weed species community composition.
\end{abstract}

Contribution/Originality: The study demonstrated the efficacy of short-term green manure cover crops in reducing weed seed bank density when they were rotated with maize. The study provides important information on the potential role of maize-cover crop rotations in integrated weed management of weeds in maize under conservation agriculture.

DOI: $10.18488 /$ journal.ajard.2021.111.139.155

$\operatorname{ISSN}(\mathrm{P}):$ 2304-1455/ ISSN(E): 2224-4433

How to cite: Rugare Joyful Tatenda --- Pieterse Petrus Jacobus --- Mabasa Stanford (2021). Influence of Short-term Maize-Green Manure Cover Crop Rotations on Germinable Weed Seed Bank under Conservation Agriculture. Asian Journal of Agriculture and Rural Development, 11(1), 139-155. 10.18488/journal.ajard.2021.111.139.155

(C) 2021 Asian Economic and Social Society. All rights reserved.

\section{INTRODUCTION}

Viable seeds and vegetative propagules that are produced by weeds are deposited in the soil by various types of dispersal agent, where they form the soil weed seed bank (Singh, Kaur, Kang, \& Singh, 2012). Since weeds produce seeds in abundance, the seed bank comprises millions of weed propagules, some of which may remain viable for extensively long periods depending on the dormancy characteristics and longevity of weed seeds in the soil (Hossain \& Begum, 2015). Soil seed banks act as reserves for viable seeds in arable fields (Chen, Liu, Zhang, Li, \& Dong, 2017). 
Therefore, targeting the soil weed seed bank is a useful integrated weed management strategy (Hossain \& Begum, 2015) and can, therefore, be used to assess the efficacy of cropping systems to reduce weed seed germination (Barberi, Bonari, \& Mazzoncini, 2001). Seed bank studies can be conducted for either the whole seed bank or specific weeds up to a specific soil depth, to determine the impact of cropping systems on weed seed bank density and species composition (Abbas, Nadeem, Tanveer, Ali, \& Farooq, 2018). In addition, information obtained from seed bank studies is used to predict future weed infestations and is therefore a useful tool in determining the type of weed control method to use (Forcella et al., 1997). Management of the non-aerial seed bank is an important long-term weed management strategy, because it is aimed at reducing further accumulation of seeds in the seed bank by minimizing seed production and/or dispersal into the field, at the same time promoting loss of viability and death of those already in the seed bank (Hossain \& Begum, 2015).

To date, a few studies have been done to assess the role of allelopathic cover crops in arable weed management in Zimbabwe (Mhlanga, Cheesman, Maasdorp, Mupangwa, \& Thierfelder, 2015a; Mhlanga et al., 2015b; Mhlanga, Cheesman, Chauhan, \& Thierfelder, 2016). Allelopathic cover crops may produce allelochemicals as root exudates and, in the process, suppress germination of weeds in the soil. Alternatively, bioherbicidal compounds may be produced as the residues of these cover crops decompose to produce phytotoxins that can impose secondary dormancy on weeds in the seed bank, consequently suppressing both weed germination and emergence (Bezuidenhout, Reinhardt, \& Whitwell, 2012; Rueda-Ayala, Jaeck, \& Gerhards, 2015). Moreover, addition of allelochemicals to the soil may reduce weed seed bank density by creating a microenvironment that promotes predation and rotting of weed seeds (Nichols, Verhulst, Cox, \& Govaerts, 2015). For example, an increase in soil moisture of $6-24 \%$ in fields mulched with cover crop residues resulted in a rise in microbial populations and a concomitant increase in wild oat (Avena fatua L.) mortality of 23-88\% (Mickelson \& Grey, 2006), and reduced seed viability in the range $41-69 \%$ (Abbas et al., 2018). Surface mulching of soils with cover crop residues results in an increase in the population of phytophagous soil-inhabiting insects like beetles and crickets, which reduce weed seedling emergence by $5-15 \%$ thereby demonstrating their potential to reduce weed seed bank size in cropping systems (Nichols et al., 2015; White, Renner, Menalled, \& Landis, 2007). Additionally, cover crops can be used to stimulate suicidal germination of crop-bound parasitic weeds like witch weeds (Striga spp.) (Muoni \& Mhlanga, 2014; Reinhardt \& Terfamichael, 2011). For example, Khan, Pickett, Wadhams, Hassanali, and Midega (2006) reported reduced Striga parasitism when the cover crop Desmodium spp. was rotated or intercropped with maize.

Previous research on the potential role of green manure cover crops (GMCCs) in weed management concentrated on their effect on weed seedling emergence without paying much attention to their effect on weed seed bank dynamics (Mhlanga et al., 2015a; Mhlanga et al., 2015b; Mhlanga et al., 2016). Management of the soil seed bank is a key strategy that ensures the control of weeds before they emerge and damage the crop. The objective of this study was to evaluate the effect of one and two-year maize-legume cover crop rotations on weed seed bank density, richness, evenness, and diversity under conservation agriculture (CA) conditions. It was hypothesised that there are some, among the cover crops tested, that are effective in reducing the size and species composition of the soil seed bank within two rotations and may thus be proposed for inclusion in smallholder CA.

\section{MATERIALS AND METHODS}

\subsection{Study Site}

The study was carried out at UZ and CIMMYT Zimbabwe station fields between August 2014 and March 2017. UZ Fields A and B are situated at the University of Zimbabwe's Crop Science Department (31 ${ }^{\circ} 05^{\prime} \mathrm{E} 18^{\circ} 12^{\prime} \mathrm{S}$ and $1523 \mathrm{~m}$ above sea level) (Chitagu, Rugare, \& Mabasa, 2014). The CIMMYT plot is located at the UZ Farm (31 ${ }^{\circ} \mathrm{O} 3^{\prime} \mathrm{E}$ $18^{\circ} 22^{\prime} \mathrm{S}$ and altitude of $1503 \mathrm{~m}$ above sea level), $20 \mathrm{~km}$ North of Harare (Mhlanga et al., 2016). Both sites lie in Zimbabwe's agro-ecological Region IIa according to classification of agroecological regions in Zimbabwe, and receive rainfall of $800-1000 \mathrm{~mm}$ per annum. Mean daily maximum temperature at both sites is $30{ }^{\circ} \mathrm{C}$. Germination of weed seeds in the soil samples taken from different green manure cover crop plots in the field was done in a glasshouse at UZ. The soils at both experimental sites are classified as chromic luvisols (Nyamapfene, 1999). The pysicochemical properties of the soils in the fields in this study are presented in Table 1.

Table 1. Physicochemical properties of soils in the study

\begin{tabular}{l|c|c|c}
\hline Soil propertu & UZ field A & UZ field B & CIMMYT \\
\hline$\%$ Clay & 18 & 16 & 26 \\
\hline$\%$ Silt & 16 & 17 & 16 \\
\hline$\%$ Sand & 66 & 67 & 58 \\
\hline Ca me \% & 7.61 & 9.19 & 6.34 \\
\hline $\mathrm{Mg}$ me \% & 4.17 & 4.67 & 2.86 \\
\hline $\mathrm{K} \mathrm{me} \mathrm{\%}$ & 0.32 & 0.46 & 0.33 \\
\hline $\mathrm{Na} \mathrm{me} \%$ & 0.22 & 0.24 & 0.62 \\
\hline $\mathrm{CEC} \mathrm{me} \mathrm{\%}$ & 12.32 & 14.56 & 10.15 \\
\hline$\% \mathrm{H}_{2} \mathrm{O}$ & 2.98 & 3.10 & 3.16 \\
\hline$\%$ Organic carbon & 1.66 & 1.53 & 2.15 \\
\hline pH $\left(\mathrm{CaCl}{ }_{2}\right)$ & 5.20 & 5.40 & 4.60 \\
\hline$\%$ Organic matter & 3.32 & 3.05 & 4.31 \\
\hline Note: me milliequivalents percent. & & &
\end{tabular}




\subsection{Treatments and History of Sampled Plots}

Soil samples used in the seed bank study were taken at the beginning of the maize phase of the rotation from plots in which maize was rotated with different GMCCs. Red Sunn hemp [Crotalaria ochroleuca (G.) Don], black Sunn hemp (Crotalaria juncea L.), common rattlepod (Crotalaria grahamiana Wight \& Arnd), tephrosia (Tephrosia vogelli L.), showy rattlebox (Crotalaria spectabilis Roth), and radish (Raphanus sativas L.) were dribbled in separate plots in rows $0.45 \mathrm{~m}$ apart, targeting an intra-row spacing of $0.25 \mathrm{~m}$ to achieve a plant density of 444,444 plants ha ${ }^{-1}$. Velvet bean [Mucuna pruriens (L.) DC], hyacinth bean [Lablab purpureus (L.) Sweet], jack bean [Canavalia ensiformis (L.) DC], and common bean (Phaseolus vulgaris L.) were planted in rows $0.45 \mathrm{~m}$ apart, targeting an intra-row spacing of $0.25 \mathrm{~m}$ to achieve a plant population per hectare of 88,888 . Cover crops and maize were grown under dry-land conditions except in the first cover crop phase in UZ Field A, where they were grown under irrigation between August and December 2014. These cover crops were selected because they are under evaluation as potential rotational crops for smallholder CA in Zimbabwe. Cover crops were grown in plots with a gross plot size of $31.5 \mathrm{~m}^{2}(6.3 \mathrm{~m} \times 5 \mathrm{~m})$ and net plot size of $18 \mathrm{~m}^{2}(4.5 \mathrm{~m} \mathrm{x} 4 \mathrm{~m})$. The field layout was a randomized complete block design (RCBD), with three blocks in each field.

In UZ Field A, the rotation commenced in August 2014 with the sowing of cover crops under sprinkler irrigation. The GMCCS were chopped down with a hand-slasher and the residues uniformly spread over the same plots in which they were grown. Thereafter, maize variety SC403 was planted in January 2015. Rotation was repeated in the summer season of 2015-16 with the planting of cover crops in the same plots where they were sown in the first cover crop phase of the rotation, followed by a uniform maize crop in the $2016-17$ cropping season. In UZ Field B the rotation was commenced with the planting of cover crops in January 2015, and these were allowed to grow for nine months. Thereafter, cover crops were slashed down, spread over their respective plots, and maize was then planted in December 2015. At CIMMYT, the rotation was initiated in the summer cropping season (December 2015 to July 2016), and maize was grown in the next cropping season (2016-17). The trial was done under no-tillage conditions, and planting of both maize and cover crops was done in furrows opened by a hoe.

\subsection{Seed Bank Sampling and Analysis}

The glasshouse experiment was laid out as a $3 \times 10$ factorial in a split-plot design with seven blocks. The main factor was soil sampling depth with three levels $(0-5 \mathrm{~cm}, 5-20 \mathrm{~cm}$, and $10-15 \mathrm{~cm})$, and the subplot factor was the maize-cover crop type at ten levels as described earlier. Soil samples were collected at the beginning of the maize phase of the rotation in the respective plots using an auger of $0.12 \mathrm{~m}$ diameter, from three sampling positions per net plot. A total of nine soil samples (three samples per sampling position) were collected from each plot. Consequently, a total of 270 samples were collected at each site. Each set of three samples from the same treatment were mixed according to depth to produce a composite (Chen et al., 2017) sample, resulting in a total of 90 representative samples for each depth per respective field. The soil samples were dried in the glasshouse to prevent germination of weeds and were stored at room temperature in the field laboratory until further use. Estimation of the weed seed bank size and community composition was done using the seedling emergence method (Mandumbu, Musvosvi, \& Rugare, 2010). Each soil sample was placed in a plastic tub of $9.5 \mathrm{~cm}$ base diameter x $4.3 \mathrm{~cm}$ height to a depth of $3 \mathrm{~cm}$. Seven representative subsamples from each soil depth per cover crop were obtained, totaling 210 representative samples. The tubs were placed on tables in a glasshouse and were watered initially to field capacity to maintain adequate moisture for germination of weed seeds. Thereafter, the pots were watered daily with $100 \mathrm{ml}$ of tap water using a perforated cup. Temperature in the glasshouse was not controlled, but day and night temperature ranged $28-29^{\circ} \mathrm{C}$ and 18-19 ${ }^{\circ} \mathrm{C}$, respectively. Weed seedlings were identified, counted by species, recorded, and removed daily for 14 days. After two weeks, the soil from each pot was turned to promote germination of photoblastic weed seeds and watered to field capacity. The identification process continued for the next 14 days. The samples were then placed in a cold room at $4^{\circ} \mathrm{C}$ for two weeks to break weed seed dormancy (Mandumbu et al., 2010). Thereafter, the pots were returned to the glasshouse where they were watered, and the process described above was repeated every fortnight for another four weeks.

\subsection{Calculation of Species Composition Parameters}

The total number of weeds that germinated for the duration of the experiment in the respective pots was converted to weed density $\mathrm{m}^{-2}$. The relative contribution of each weed species to the seed bank was expressed as percentage of total weed density $\mathrm{m}^{-2}$ (Morris et al., 2015). Weed species diversity was calculated using species richness and evenness by Equations 1 and 2 as follows:

$$
\begin{aligned}
& \mathrm{pi}=\mathrm{ni} / \mathrm{N} \\
& \mathrm{H}=-\sum \mathrm{pi} *(\ln (\mathrm{pi}))
\end{aligned}
$$

where ni $=$ number of weeds of species, $\mathrm{N}=$ total number of weeds of all species observed, pi $=$ relative abundance of species (Equation 1) and $\mathrm{H}=$ the Shannon diversity index (Equation 2) (Mtambanengwe et al., 2015). Evenness (E) was calculated as follows:

$\mathrm{E}=\mathrm{H} / \ln \mathrm{N}$

where $\mathrm{E}=$ relationship between the observed and total number of species (Mhlanga et al., 2015a).

\subsection{Data Analysis}

Analysis of variance (ANOVA) was carried out on all parameters using Genstat (14 ${ }^{\text {th }}$ edition). All data were subjected to the Shapiro-Wilk test for normality testing, and data that did not meet the assumptions of ANOVA were transformed $\log _{10}(x)$ and $\sqrt{ }(x+0.5)$ transformed. Mean separation was done using the least significant 
differences (Lsd) test at the 0.05 probability level. The models (Gomez \& Gomez, 1984; Little \& Hills, 1978) used to perform the (1) combined-season ANOVA for data obtained from UZ fields and (2) one-season ANOVA for CIMMYT fields are given below:

$\mathrm{Y}_{\mathrm{ijk}}=\mu+\mathrm{S}_{\mathrm{k}}+\mathrm{D}_{\mathrm{j}}+\mathrm{R}_{\mathrm{k}}+\mathrm{S}_{\mathrm{i}} * \mathrm{D}_{\mathrm{j}}+\mathrm{D}_{\mathrm{j}} * \mathrm{R}_{\mathrm{k}}+\mathrm{S}_{\mathrm{i}} * \mathrm{R}_{\mathrm{k}}+\mathrm{S}_{\mathrm{i}} * \mathrm{D}_{\mathrm{j}} * \mathrm{R}_{\mathrm{k}}+\mathrm{e}_{\mathrm{ijk}}$

$Y j k=\mu+D_{j}+R_{k}+D_{j} * R_{k}+e_{i j k}$

where $\mathrm{Y}_{\mathrm{ijk}}$ is weed density in the $i$ th season, $\mu$ is overall mean weed density, $\mathrm{D}_{\mathrm{j}}$ is the effect of the $j$ th depth, and $\mathrm{R}_{\mathrm{k}}$ is the effect of the $k$ th rotation. $\mathrm{S}_{\mathrm{i}} * \mathrm{D}_{\mathrm{j}} * \mathrm{R}_{\mathrm{k}}$ is the interaction of the $i$ th season, $j$ th depth, and $k$ th rotation. $\mathrm{S}_{\mathrm{i}} * \mathrm{R}_{\mathrm{k}}$ is the interaction of the $i$ th season $* k$ th rotation, $\mathrm{D}_{\mathrm{j}} * \mathrm{R}_{\mathrm{k}}$ is the interaction of the $j$ th depth and the $k$ th rotation, $\mathrm{S}_{\mathrm{i}} * \mathrm{D}_{\mathrm{j}}$ is the interaction of the $i$ th season and the $j$ th depth, and $\mathrm{e}_{\mathrm{ijk}}$ is the error term. Maize-cover crop rotation plus maizecover crop rotation * environment interaction (GGE) analysis was carried out on the means from the acrossenvironments * maize-cover crop rotation ANOVA using Genstat (Genstat, 2011). The model for the GGE biplot used was described by Yan, Hunt, Sheng, and Szlavnics (2000) and Yan and Kang (2002) as $Y_{\mathrm{ij}}-\mu-\beta_{\mathrm{j}}={ }^{\mathrm{k}} \sum_{\mathrm{l}=1} \lambda_{\mathrm{l}} \xi_{\mathrm{il}} \eta_{\mathrm{j}}$ $+\varepsilon_{\mathrm{ij}}$, where $\mathrm{Y}_{\mathrm{ij}}$ is the average weed density of the $\mathrm{i}^{\text {th }}$ cover-crop rotation in the $\mathrm{j}^{\text {th }}$ environment; $\mu$ is the grand mean; $\beta$ is the main effect of the environment $j ; \lambda_{1}$ is the singular value of the $1^{\text {th }}$ principal component, $k=2$ in this case; $\xi_{\text {il }}$ is the eigenvector of the maize-cover crop rotation $i$ for $\mathrm{PC} l$; $\eta_{\mathrm{lj}}$ is the eigenvector of environment $j$ for $\mathrm{PC} l$; and $\varepsilon_{\mathrm{ij}}$ is the residual associated with maize-cover crop rotation $i$ in the environment $j$. Based on this model, the biplot is environment-centered using Genstat (Genstat, 2011).

\section{RESULTS}

\subsection{Weed Relative Density}

A total of 12 weed species were recorded in the soil seed bank in UZ Field A in the 2014-15 season, of which $58.3 \%$ were annual broadleaf, $25 \%$ annual grasses, and $16.7 \%$ perennial sedges. In the $2016-17$ season, species richness in the seed bank decreased to ten. Out of these, $50 \%$ were annual broadleaf, $40 \%$ annual grasses, and $10 \%$ perennial sedges. The seed bank in UZ Field B comprised $77 \%$ annual broadleaf, $15 \%$ annual grasses, and $8 \%$ perennial sedges. The seed bank at CIMMYT comprised $75 \%$ broadleaf, $16.7 \%$ annual grasses, and $8.3 \%$ perennial sedges. The dominant weeds were smooth pigweed (Amaranthus hybridus L.), blackjack (Bidens pilosa L.), goosegrass [Eleusine indica (L.) Gaertn], gallant soldier (Galinsoga parviflora L.), and Mexican clover (Richardia scabra L.). The life cycle, type of reproduction, and relative density of the weeds found in the different seed banks are presented in Table 2. The relative densities of individual species differed between years and across sites. In the 2014-15 season in UZ Field A, the primary broadleaved weed species were smooth pigweed and blackjack whilst goosegrass was the dominant grass species. In the 2016-17 season there was a general increase in both weed species number and relative density of individual species in UZ Field A. The dominant weed species in UZ Field A in the second maize phase (2016-17 season) were smooth pigweed, black jack, goosegrass, gallant soldier, and purslane (Portulaca oleracea L.). However, the relative density of pigweed decreased fivefold to $11 \%$ from a previous high of $49 \%$ in the $2014-15$ season. In 2015-16, blackjack, goosegrass, gallant soldier, and Mexican clover were the primary weed species in UZ Field B. The primary weeds at CIMMYT were smooth pigweed, gallant soldier, and Mexican clover. Goosegrass consistently maintained its position as the dominant grass species between seasons and across sites.

Table-2. Relative weed density of all species found in at $0-15 \mathrm{~cm}$ depth at all sites from which soil samples were taken.

\begin{tabular}{|c|c|c|c|c|c|}
\hline \multirow[b]{2}{*}{ Scientific name } & & \multicolumn{4}{|c|}{ Relative density (\%) } \\
\hline & $\begin{array}{c}\text { Life } \\
\text { cycle }\end{array}$ & $\begin{array}{c}\text { UZ field } \\
\text { A } \\
2014-15\end{array}$ & $\begin{array}{c}\text { UZ field } \\
\text { A } \\
2016-17\end{array}$ & $\begin{array}{c}\text { UZ field } \\
\text { B } \\
2015-16\end{array}$ & $\begin{array}{c}\text { CIMMYT } \\
2016-17\end{array}$ \\
\hline Amaranthus hybridus L. & $\mathrm{A}, \mathrm{Br}$ & 49 & 11 & 3 & 17 \\
\hline Bidens pilosa L. & $\mathrm{A}, \mathrm{Br}$ & 11 & 24 & 18 & 1 \\
\hline Commelina bengalensis $\mathrm{L}$. & $\mathrm{A}^{*}$ & 2 & - & 8 & 6 \\
\hline Eleusine indica (L.) Geartn & $\mathrm{A}, \mathrm{Gr}$ & 6 & 11 & 17 & 6 \\
\hline Urochloa panicoides Beauv. & $\mathrm{A}, \mathrm{Gr}$ & 4 & 8 & 4 & - \\
\hline Sckhuhria pinnata (Lam.) Kuntze & $\mathrm{A}, \mathrm{Br}$ & - & - & 1 & - \\
\hline Galinsoga parviflora Cav. & $\mathrm{A}, \mathrm{Br}$ & 8 & 23 & 29 & 37 \\
\hline Chenopodium album L. & $\mathrm{A}, \mathrm{Br}$ & 2 & - & 1 & - \\
\hline Portulaca oleracea L. & $\mathrm{A}, \mathrm{Br}$ & 9 & 10 & 4 & - \\
\hline Oxalis latifolia Kunth & $\mathrm{A}, \mathrm{Br}$ & 4 & - & - & - \\
\hline Cyperus esculentus L. & $\mathrm{P}, \mathrm{Se}$ & 1 & 4 & 2 & 1 \\
\hline Nicandra physaloides (L.) Gaertn & $\mathrm{A}, \mathrm{Br}$ & - & - & - & 2 \\
\hline Rottboellia conchinchinensis L.f. & $\mathrm{A}, \mathrm{Gr}$ & 1 & 2 & 1 & - \\
\hline Richardia scabra L. & $\mathrm{A}, \mathrm{Br}$ & 3 & 1 & 12 & 23 \\
\hline Setaria pumila (Poir.) Roem. \& Hideber. & $\mathrm{A}, \mathrm{Gr}$ & - & 6 & - & 2 \\
\hline Conyza albida (Retz) E.H. Walker & $\mathrm{A}, \mathrm{Br}$ & - & - & - & 3 \\
\hline Datura stramonuim L. & $\mathrm{A}, \mathrm{Br}$ & - & - & - & 2 \\
\hline Total & & 100 & 100 & 100 & 100 \\
\hline
\end{tabular}

Note: * Possesses characteristics of both monocotyledons and dicotyledons. A, anuual; Br, broadleaf; Gr, grasses. 
Table-3. Effects of maize-cover crop rotations, depth of soil sampling, and season on weed seed density and community composition.

\begin{tabular}{|c|c|c|c|c|c|}
\hline \multirow[t]{2}{*}{ Site } & & $\begin{array}{c}\text { Weed } \\
\text { seed } \\
\text { density }\end{array}$ & $\begin{array}{c}\text { Weed } \\
\text { species } \\
\text { richness }\end{array}$ & $\begin{array}{c}\text { Weed } \\
\text { species } \\
\text { diversity } \\
\end{array}$ & $\begin{array}{c}\text { Weed } \\
\text { species } \\
\text { evenness }\end{array}$ \\
\hline & Source & $p$-value & $p$-value & $p$-value & $p$-value \\
\hline \multirow{7}{*}{$\begin{array}{l}\text { UZ plot, two seasons } \\
\text { combined } \\
(2014-15 \text { and } 2016- \\
17)\end{array}$} & Season & 0.002 & 0.002 & $<0.001$ & $<0.001$ \\
\hline & Depth & $<0.001$ & $<0.001$ & 0.003 & 0.006 \\
\hline & GMCC & 0.016 & 0.229 & 0.594 & 0.902 \\
\hline & Season * Depth & 0.028 & 0.276 & 0.258 & 0.228 \\
\hline & Season * GMCC & $<0.001$ & 0.053 & 0.012 & 0.136 \\
\hline & Depth * GMCC & 0.001 & 0.357 & 0.143 & 0.463 \\
\hline & Season * Depth * GMCC & 0.216 & 0.152 & 0.322 & 0.780 \\
\hline \multirow{3}{*}{$\begin{array}{l}\text { UZ new plot } \\
(2015-16)\end{array}$} & Depth & 0.011 & - & - & - \\
\hline & GMCC & 0.007 & - & - & - \\
\hline & GMCC * Depth & 0.014 & - & - & - \\
\hline \multirow{3}{*}{$\begin{array}{l}\text { CIMMYT plot } \\
(2016-17)\end{array}$} & Depth & $<0.001$ & - & - & - \\
\hline & GMCC & $<0.002$ & - & - & - \\
\hline & GMCC * Depth & 0.110 & - & - & - \\
\hline
\end{tabular}

\subsection{UZ Field A Total Weed Seed Density (Seasons 2014-15 and 2016-17)}

Table 3 shows the effects of season, depth of soil sampling, and maize-cover crop rotations on weed seed density, species richness, diversity, and evenness. Combined ANOVA for seasons 2014-15 and 2016-17 showed that the seasons * depth of sampling * maize-cover crop rotation interaction on weed seed density in UZ Field A was not significant $(p>0.05)$ (Table 3). However, depth of sampling * season, season * maize-cover crop rotation and depth of sampling * maize-cover crop rotation interactions were significant $(p<0.05)$. Weed seed density was significantly $(p<0.05)$ lower across all maize-cover crop rotations in the 2016-17 season compared to the 2014-15 season (Figure 1A) except where common rattlepod, tephrosia, showy rattlebox and jack bean were rotated with maize. Weed density in maize-after-maize control increased by 4.8\% in 2016-17 compared to 2014-15, although the increase was not significant. However, the influence of different maize-cover crop rotations on weed seed density did not differ within the same season in either season. Significant reductions in weed seed bank size were observed in maize-aftermaize, maize-black Sunn hemp, maize-velvet bean and maize-hyacinth bean rotations as soil sampling depth was increased from $\mathrm{O}-5$ to $10-15 \mathrm{~cm}$ depth (Figure $1 \mathrm{~B}$ ). In the maize-pigeon pea rotation, weed density was significantly higher at $10-15 \mathrm{~cm}$ depth compared to $5-10 \mathrm{~cm}$.
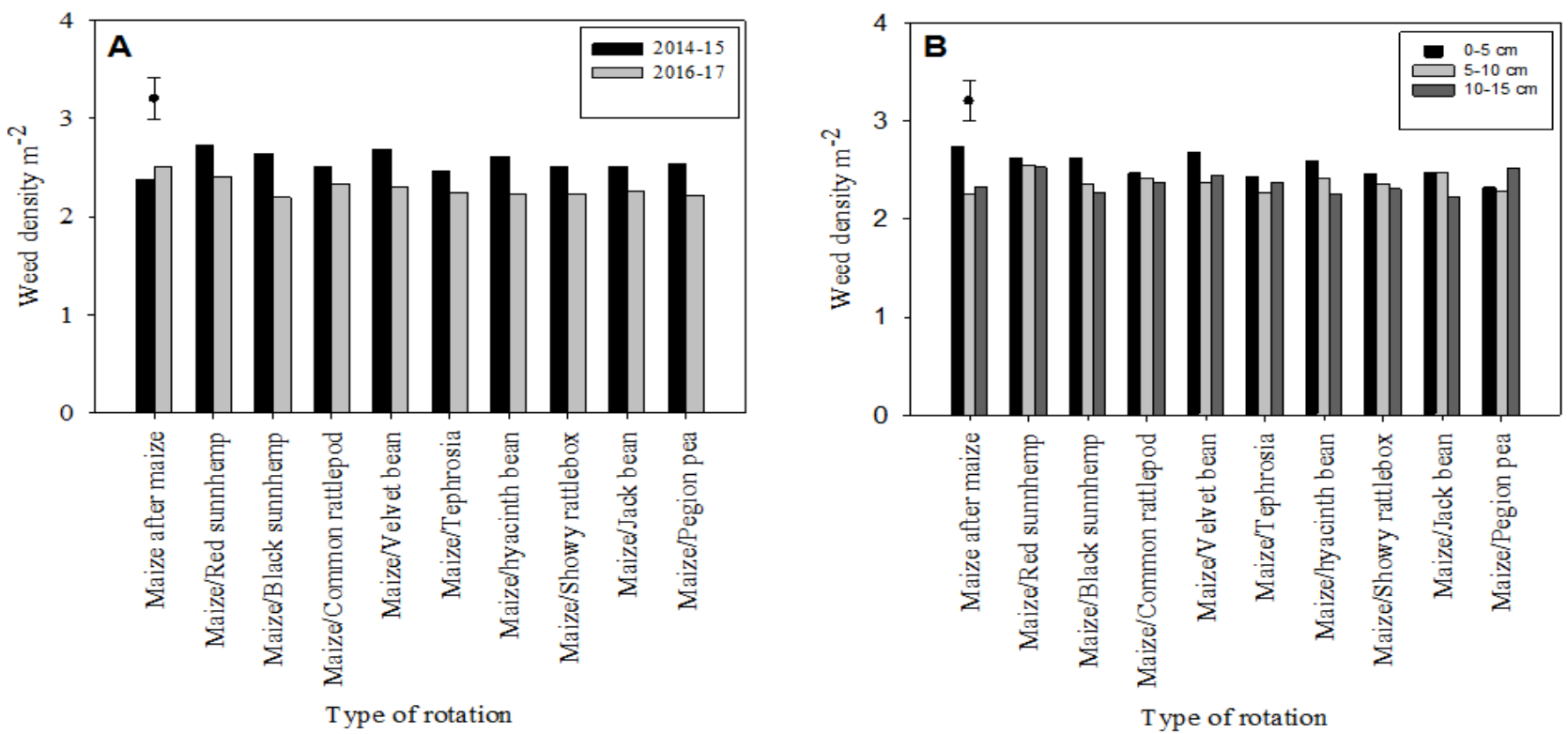

Figure-1. Effects of (A) cover crop and season on weed density seasons and (B) cover crop and sampling depth on weed seed density in $2014-15$ and 2016-17. Data were $\log _{10}(x)$ transformed.

The interaction between season and sampling depth on weed seed density in UZ Field A was significant $(p<$ 0.05). There was a significant $(p<0.05)$ decline in weed seed density at $0-5 \mathrm{~cm}$ soil sampling depth in the $2016-17$ compared to the 2014-15 season (Figure 2). However, weed seed density did not differ at depths of 5-10 $\mathrm{cm}$ and $10-$ $15 \mathrm{~cm}$ between the 2014-15 and 2016-17 seasons. 


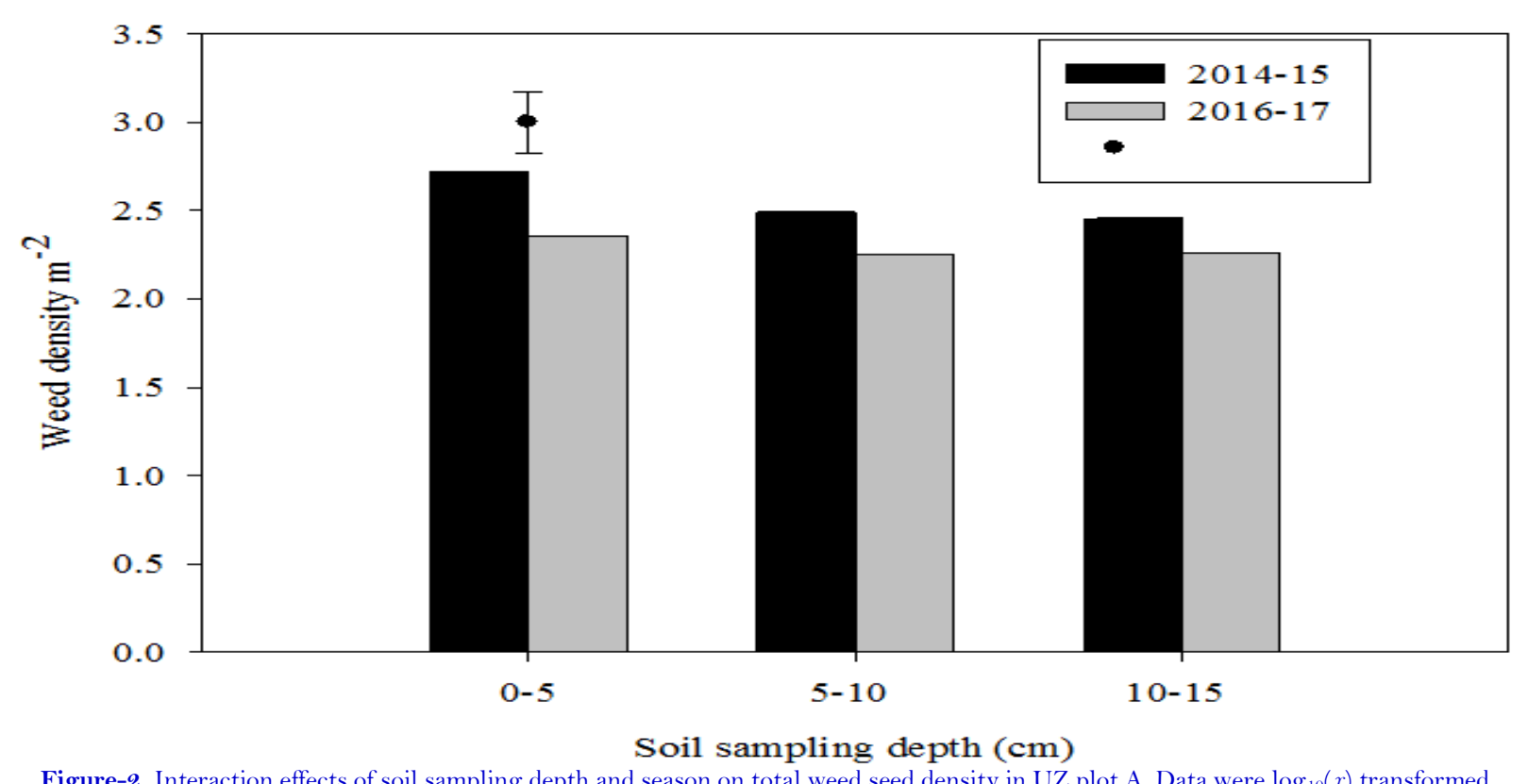

\subsection{UZ Field B Total Weed Density (2015-16)}

Weed seed bank studies done in UZ Field B in one season (2015-16) showed that there was a significant interaction $(p<0.05)$ between soil sampling depth and maize-cover crop rotation on weed seed density. Weed seed density in the maize-jack bean, maize-velvet bean and maize-red Sunn hemp rotations was significantly higher at 0 $5 \mathrm{~cm}$ depth compared to 5-10 and 10-15 cm depth, which did not differ in seed bank size (Figure 3). Weed seed density at $0-5$ and $5-10 \mathrm{~cm}$ depth was the same as in the maize-after-maize, maize-black Sunn hemp, maize-hyacinth bean and maize-showy rattlebox rotation,s but was significantly higher than in the 10-15 cm layer. Maize-common rattlepod and maize-tephrosia rotations did not affect total weed seed density across all sampling depths.

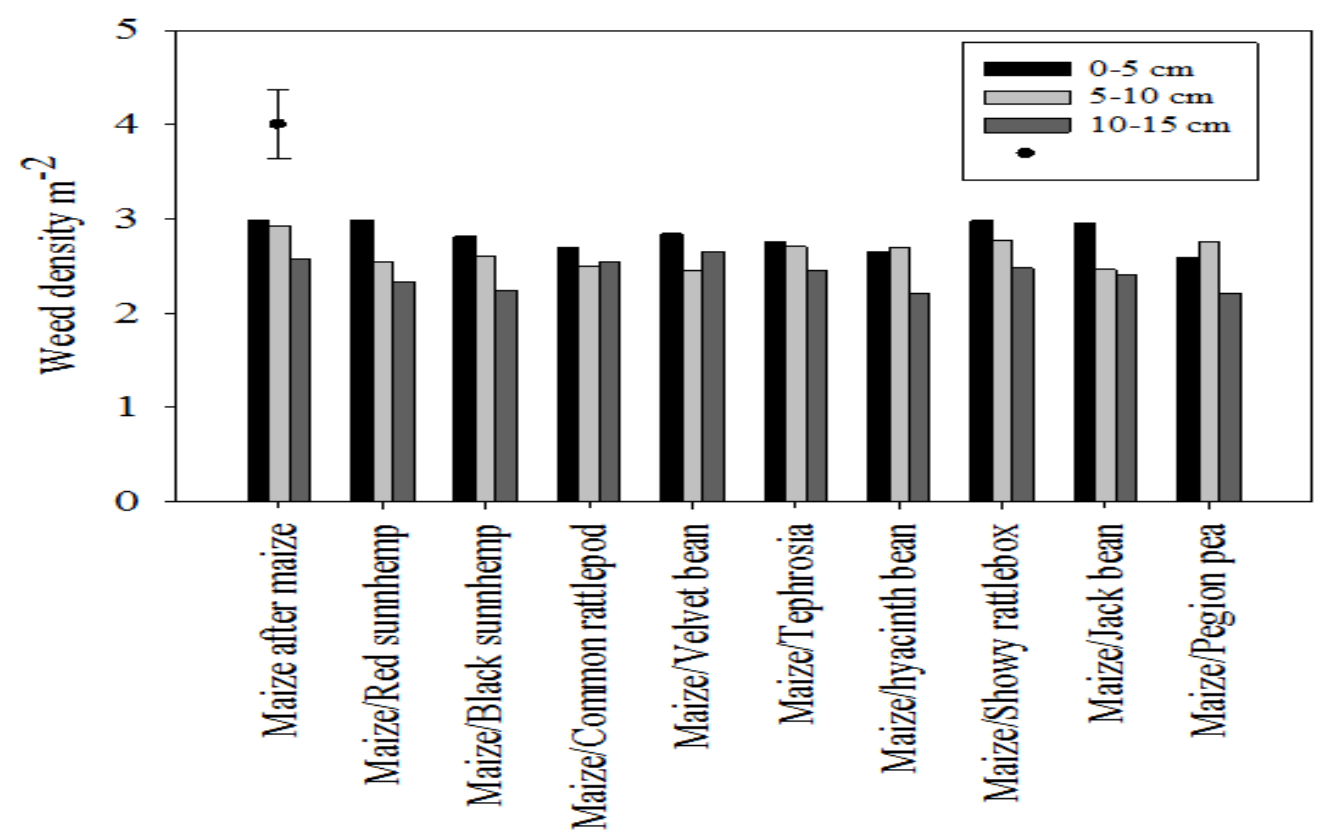

Type of rotation

Figure-3. Interaction effects of soil sampling depth and maize-cover crop rotation on weed seed density in UZ Field B in 2015-16. Data were $\log _{10}(x)$ transformed.

\subsection{CIMMYT Total Weed Density (2016-17 Season)}

The cover crop * sampling depth interaction was not significant $(p<0.05)$ at CIMMYT. There were variations in weed seed bank size in the different soil layers, with significantly $(p<0.05)$ higher densities in the upper layers. Weed seed density significantly $(p<0.05)$ decreased from the $0-5 \mathrm{~cm}$ depth as sampling depth was increased (Figure $4 \mathrm{~A})$. A comparison of the influence of different cover crop rotations showed that there were significant $(p<0.05)$ treatment effects on weed seed bank size (Figure 4B). Weed seed density was 55 and $40 \%$ lower in the maize-red Sunn hemp and maize-pigeon pea rotations compared to the maize-after-maize control. The other maize cover crop rotations were the same as the maize-after-maize control. 

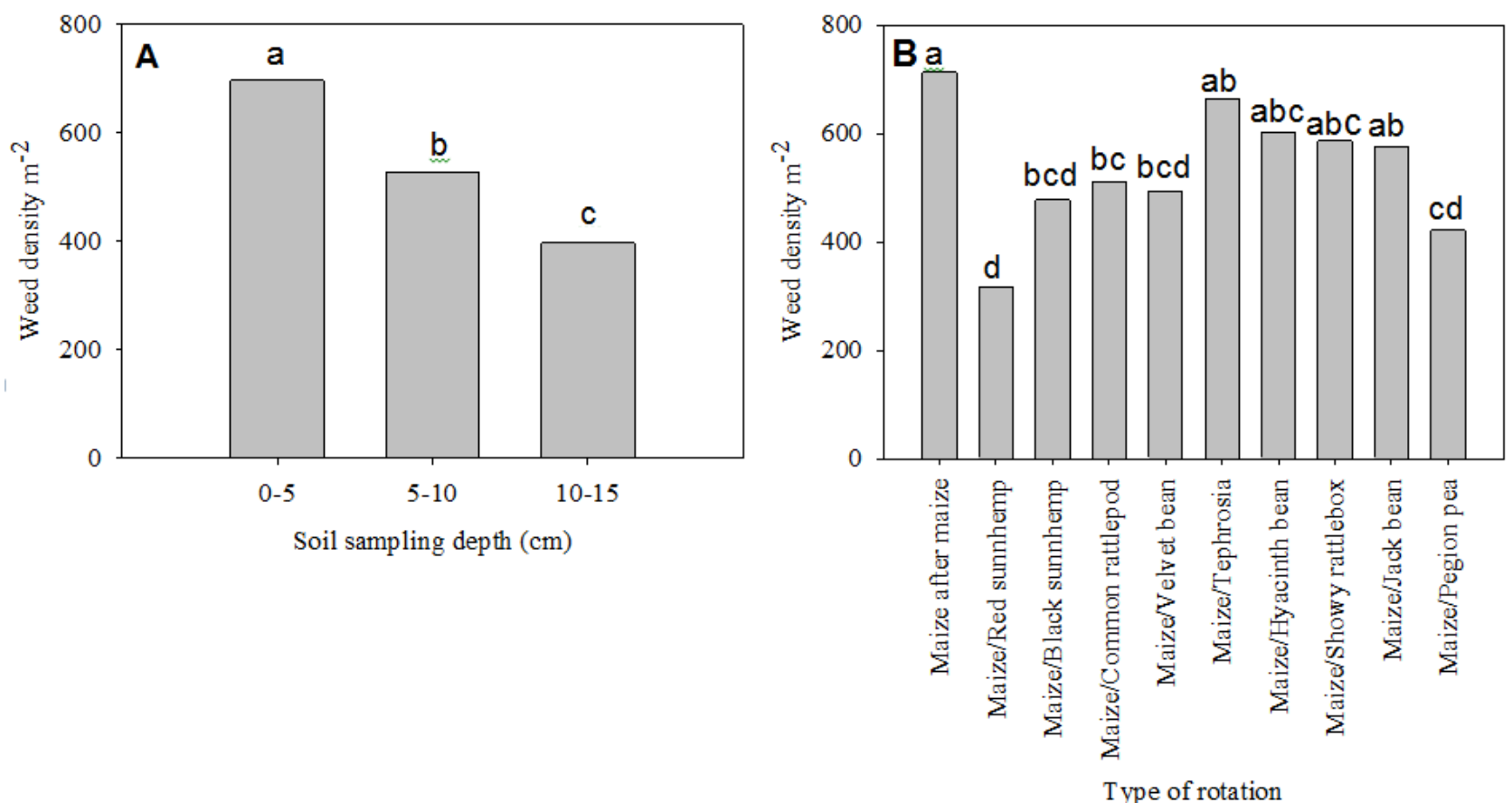

Figure-4. Effects of (A) soil sampling depth and (B) crop rotation on weed seed density at CIMMYT in the $2016-17$ season.

Figure 5 shows the effect of the different rotations on total weed seed density at all the sites in different seasons. In all plots, total weed seed density was highest in the maize-after-maize control, followed by the maize-showy rattlebox and maize-tephrosia rotations. The biplot shows that the different sites and seasons can be grouped into one mega-environment.

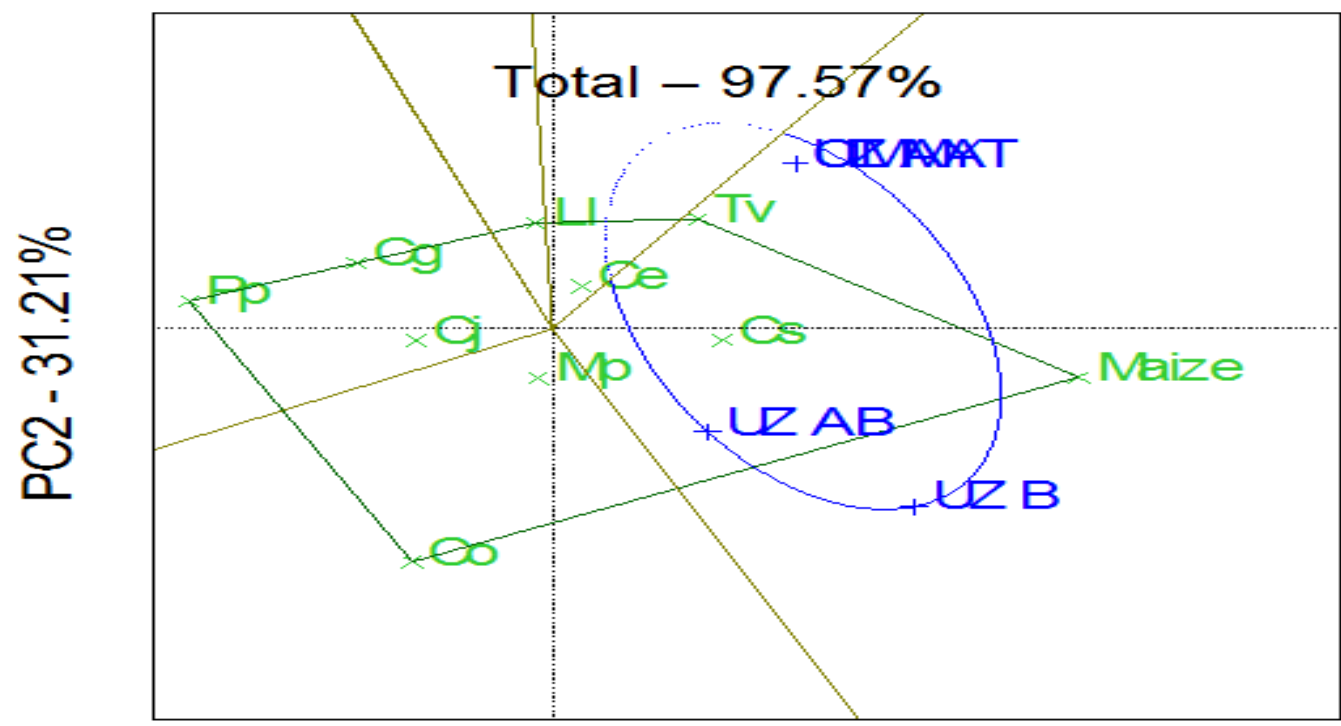

PC1 - 66.36\%

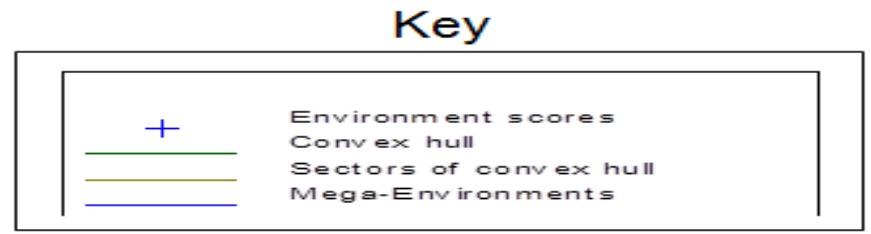

Figure-5. Which-won-where biplot showing the influence of maize-cover crop rotations on total weed density in the different plots across seasons. Co, red Sunn hemp; Cj, black sunnhemp; Cg. common rattlepod; Mp, velvet bean; Tv, tephrosia; Ll, hyacinth bean; Cs, showy rattlebox; Ce, jack bean; Pp, pigeon pea; UZAA, UZ Field A 2014-15 season; UZAB, UZ Field A 2016-17 season; UZB, UZ Field B 2015-16 season; CIMMYT (2016-17 season). 
3.5. Weed Species Richness, Diversity, and Evenness

3.5.1. UZ Field A (Combined Seasons Analysis 2014-15 and 2016-17)

There were no significant $(p>0.05)$ interactions between season, depth, and cover crop type on weed species richness and evenness in UZ Field A between 2014 and 2017 (Table 3). The effect of maize cover crop type on species richness and evenness was not significant $(p>0.05)$ (Table 4$)$.

Table-4. Effect of maize-cover crop rotations on weed species richness and evenness indices in UZ Field A (2014-15/2016-17).

\begin{tabular}{l|c|c}
\hline Rotation & Species richness & Species evenness \\
\hline Maize-after-maize & $1.51(2.08)$ & $0.92(0.41)$ \\
\hline Maize/red Sunn hemp & $1.39(1.60)$ & $0.86(0.27)$ \\
\hline Maize/black Sunn hemp & $1.50(1.95)$ & $0.90(0.35)$ \\
\hline Maize/Common rattlepod & $1.31(1.48)$ & $0.88(0.32)$ \\
\hline Maize/Velvet bean & $1.39(1.69)$ & $0.91(0.37)$ \\
\hline Maize/Tephrosia & $1.35(1.52)$ & $0.89(0.34)$ \\
\hline Maize/Lablab & $1.38(1.64)$ & $0.91(0.38)$ \\
\hline Maize/Showy rattlebox & $1.38(1.65)$ & $0.88(0.32)$ \\
\hline Maize/Jack bean & $1.39(1.55)$ & $0.92(0.39)$ \\
\hline Maize/Pigeon pea & $1.28(1.33)$ & $0.88(0.32)$ \\
\hline $\boldsymbol{P}$-value & $\mathbf{0 . 2 2 9}$ & $\mathbf{0 . 9 0 2}$ \\
\hline $\mathbf{C V \%}$ & $\mathbf{2 9 . 7}$ & $\mathbf{2 1 . 1}$ \\
\hline
\end{tabular}

Note: Data were $\log _{10}(x)$ transformed; untransformed data shown in parentheses.

There was a significant $(p<0.05)$ effect of soil sampling depth on weed species richness and evenness in UZ Field A (Figure 6A,C). Both species richness and evenness were significantly higher at $0-5 \mathrm{~cm}$ depth compared to the other sampling depths, which had similar species richness and evenness. Weed species richness and evenness significantly $(p<0.05)$ decreased in 2016-17 compared to 2014-15 (Figure 6B,D).
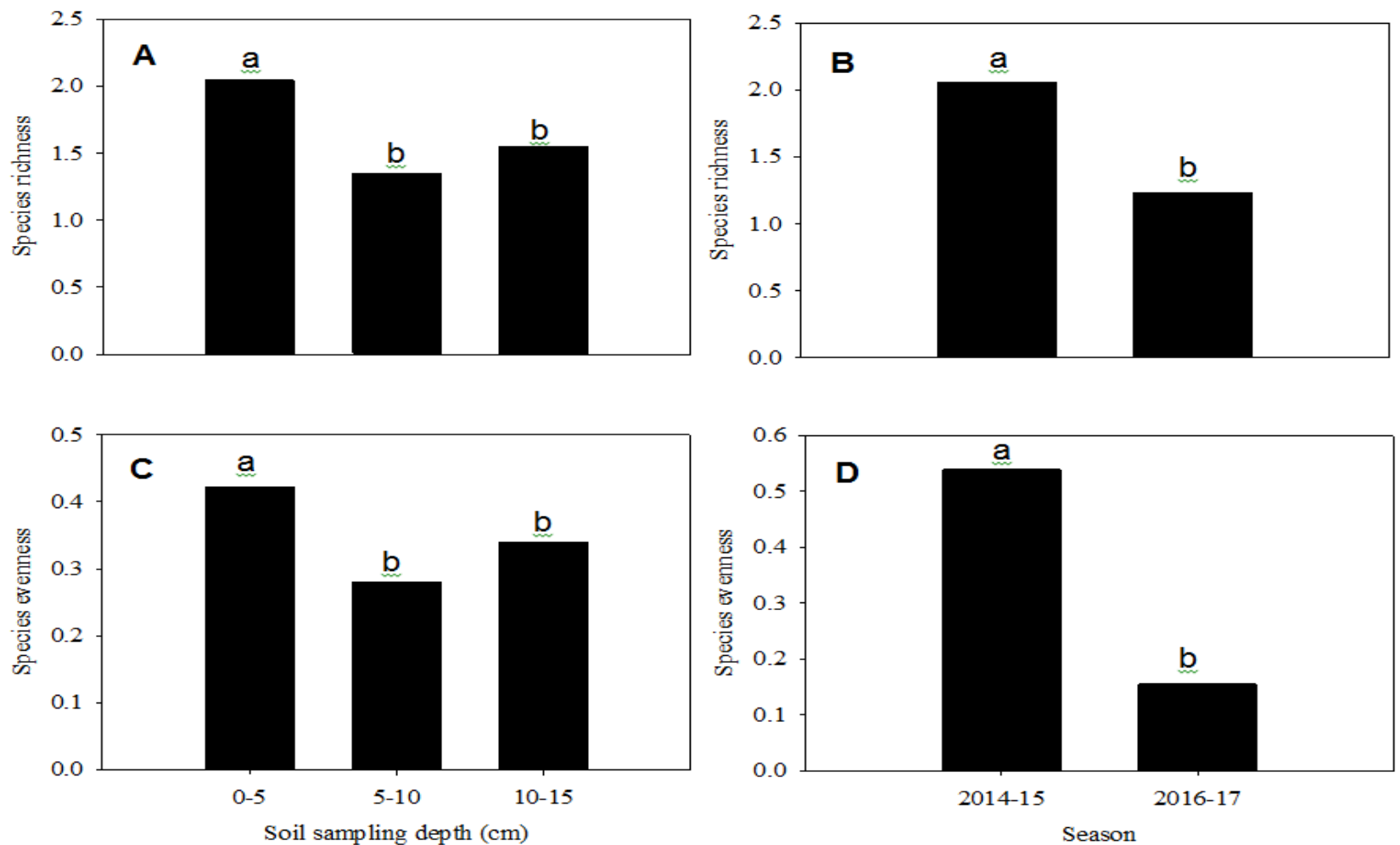

Figure-6. Effect of soil sampling depth (A,C) and season (B,D) on weed species richness and evenness $\left(\mathrm{m}^{-2}\right)$ at UZ Field A in seasons $2014-15$ and $2016-17$.

However, the season * maize-cover crop rotation interaction was significant $(p<0.05)$ on weed species diversity (Figure 7). The Shannon-Weiner diversity indices for maize-after-maize and maize-red Sunn hemp remained unchanged in both seasons. In contrast, weed species diversity indices in the other maize-cover crop rotations were significantly lower in 2016-17 compared to 2014-15. 


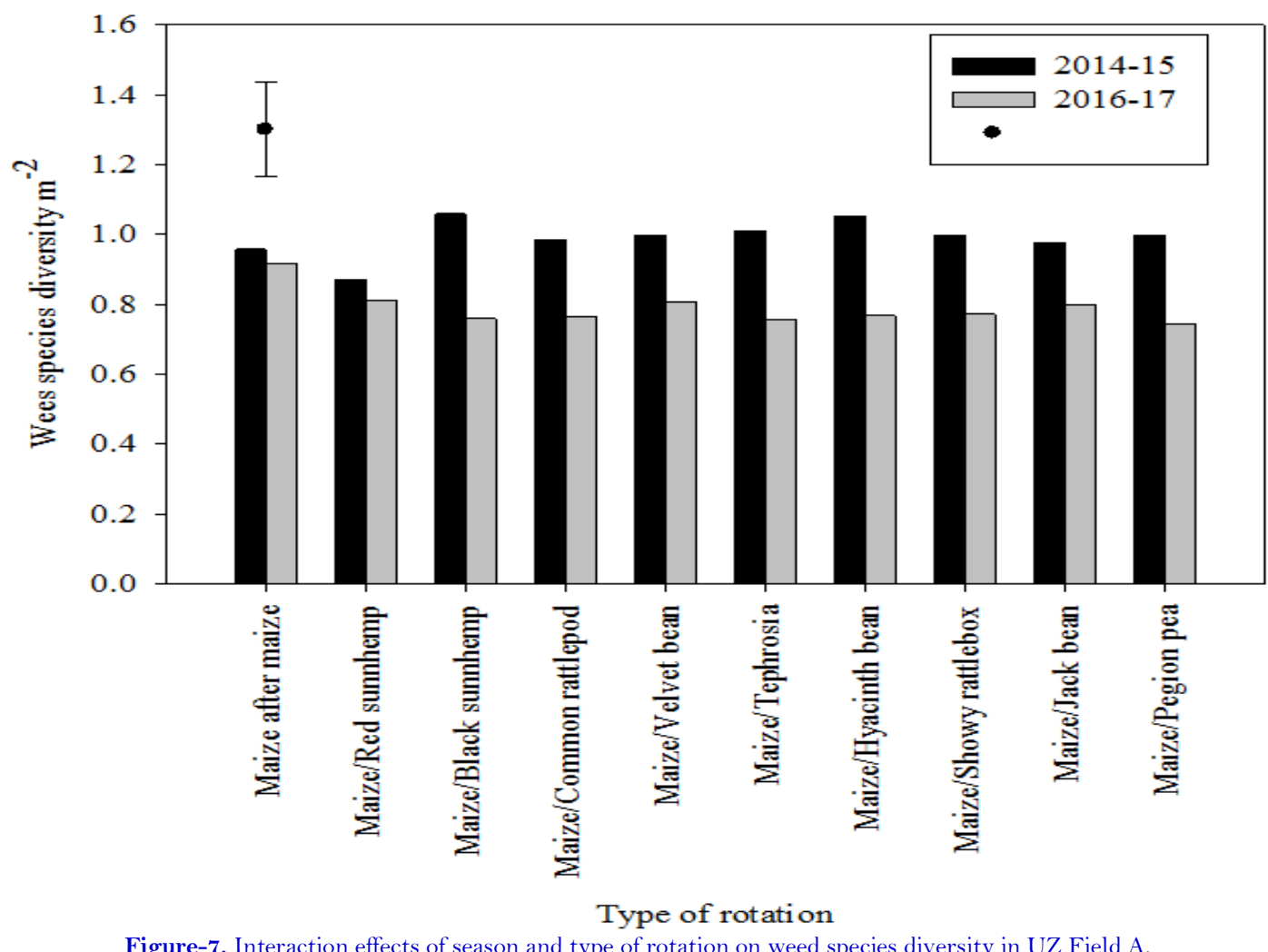

The effect of sampling depth on weed species diversity was significant $(p<0.05)$. Weed species diversity was 10.3 and $6.4 \%$ higher in the $0-5 \mathrm{~cm}$ soil layer compared to $5-10$ and $10-15 \mathrm{~cm}$, respectively (Figure 8 ).

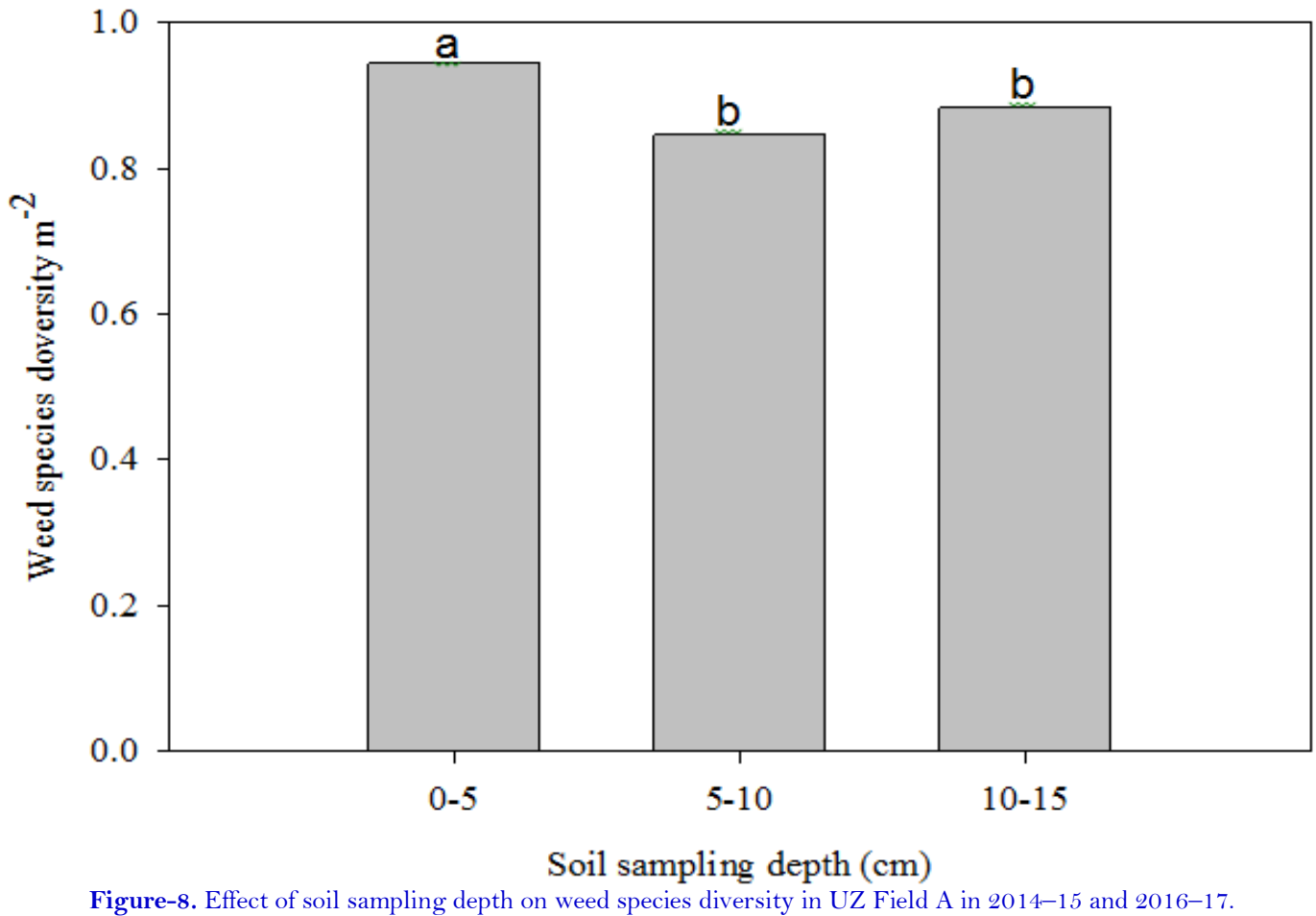

3.6. Response of Major Weed Species to Different Cover Crop Rotations at Different Sites and Across Seasons

Table 5 summarizes the ANOVA values for major weeds in different fields. 
Table-5. ANOVA values explaining the effects of different maize-cover crop rotations, depth of soil sampling, and season on densities of major weeds in different fields.

\begin{tabular}{|c|c|c|c|c|c|}
\hline \multirow[t]{2}{*}{ Site } & & Blackjack & $\begin{array}{l}\text { Smooth } \\
\text { pigweed }\end{array}$ & $\begin{array}{l}\text { Gallant } \\
\text { soldier }\end{array}$ & Goosegrass \\
\hline & Source & $p$-value & $p$-value & $p$-value & $p$-value \\
\hline \multirow{7}{*}{$\begin{array}{l}\text { UZ plot, } \\
2014-15 \text { and 2016-17 } \\
\text { combined }\end{array}$} & Season & 0.072 & $<0.001$ & 0.755 & 0.186 \\
\hline & Depth & 0.254 & 0.251 & $<0.001$ & 0.144 \\
\hline & GMCC & $<0.001$ & $<0.001$ & $<0.001$ & 0.066 \\
\hline & Season * Depth & $<0.001$ & $<0.001$ & $<0.001$ & 0.175 \\
\hline & Season * GMCC & $<0.001$ & $<0.001$ & $<0.001$ & 0.211 \\
\hline & Depth * GMCC & $<0.001$ & $<0.001$ & $<0.001$ & 0.079 \\
\hline & Season * Depth * GMCC & 0.002 & 0.270 & $<0.001$ & 0.288 \\
\hline \multirow{4}{*}{$\begin{array}{l}\text { UZ new plot, } \\
2015-16\end{array}$} & Depth & 0.998 & 0.363 & 0.330 & - \\
\hline & GMCC & $<0.001$ & 0.787 & 0.086 & - \\
\hline & Season * Depth & 0.001 & 0.860 & 0.023 & - \\
\hline & & & & & Mexican clover \\
\hline \multirow{3}{*}{$\begin{array}{l}\text { CIMMYT plot, } \\
2016-17\end{array}$} & Depth & - & 0.180 & $<0.001$ & 0.379 \\
\hline & GMCC & - & 0.396 & 0.004 & 0.090 \\
\hline & Season * Depth & - & 0.093 & 0.001 & 0.129 \\
\hline
\end{tabular}

\subsubsection{UZ Field A (2014-15 And 2016-17 Seasons)}

Combined season ANOVA for the 2014-15 and 2016-17 seasons was performed on major weeds in UZ Field A, and the results are presented in Figures 10-13. There was a significant $(p<0.05)$ season * depth * maize-cover crop rotation interaction on the density of blackjack (Figure 9). Blackjack density was significantly $(p<0.05)$ higher in the 2016-17 season than the 2014-15 season at 5-10 and 10-15 cm in the maize-after-maize, showy rattlebox, and jack bean rotations only. The density of blackjack did not significantly change between seasons and across the three sampling depths in the other maize-cover crop rotations.
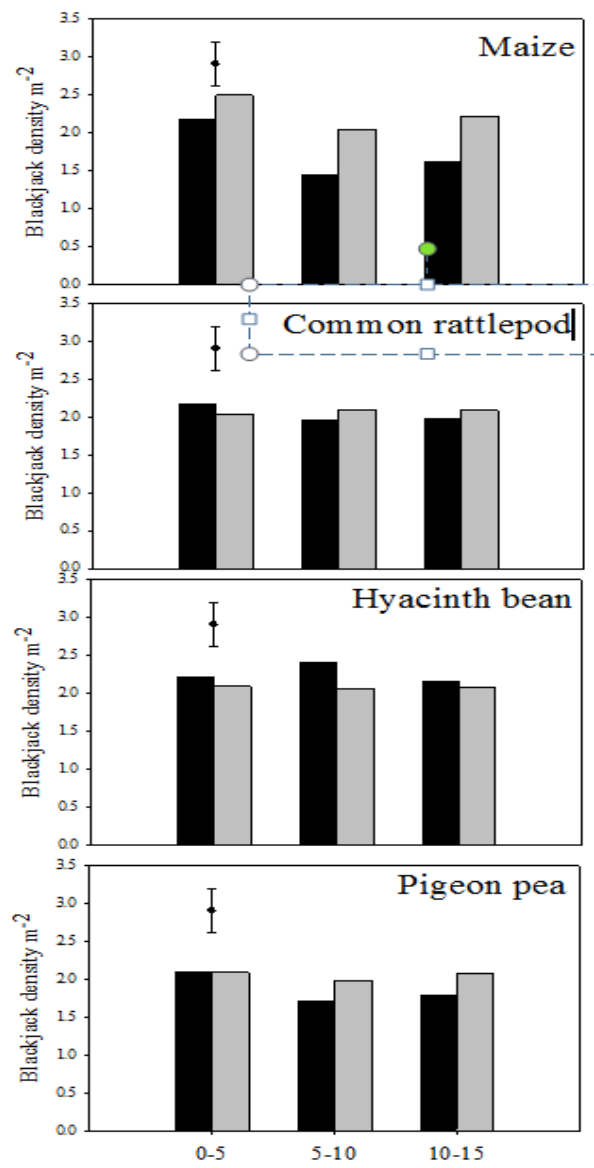

Soil sampling depth $(\mathrm{cm})$

Figure-9. Response of blackjack density to different maize-cover crop rotations and soil depths across seasons. Data were $\log _{10}(x)$ transformed
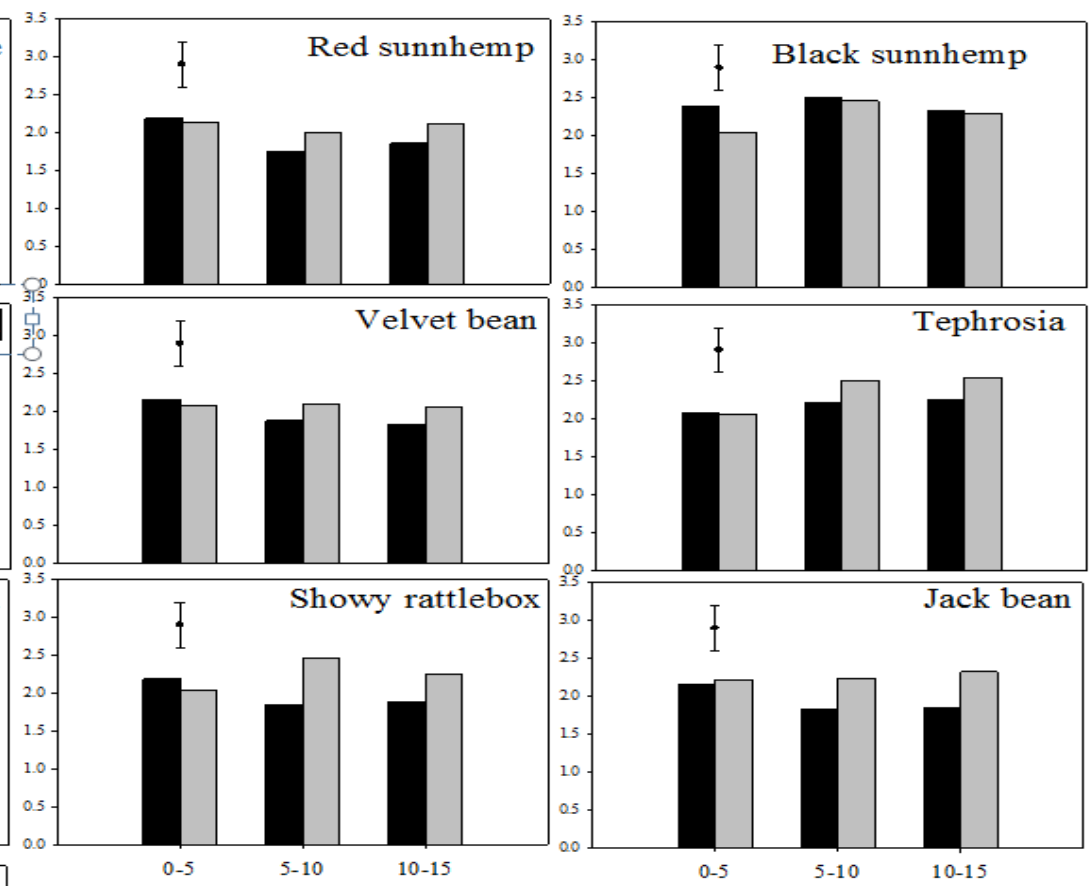

Soil sampling depth $(\mathrm{cm})$
Soil sampling depth $(\mathrm{cm})$

There was no significant $(p>0.05)$ interaction of season, depth, and maize-cover crop rotation on goosegrass density in UZ Field A between 2014 and 2017. Goosegrass density was not significantly $(p>0.05)$ influenced by the type of maize-cover crop rotation that was used (Figure 10A). The density of goosegrass did not vary significantly $(p$ 
$>0.05)$ in the different layers of the soil profile (Figure 10B). There were no significant $(p>0.05)$ differences in goosegrass density between the 2014-15 and 2016-17 seasons (Figure 10C).
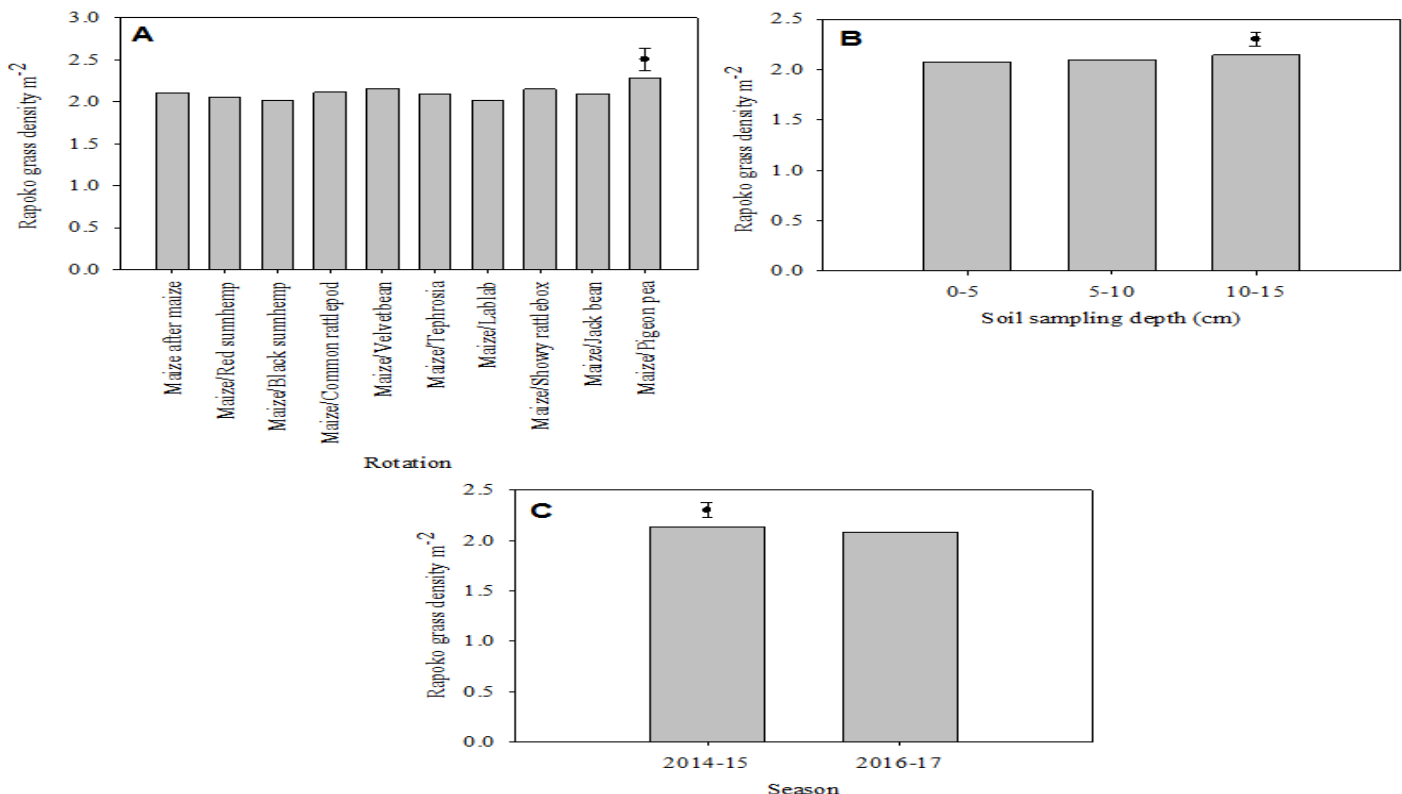

Figure-10. Response of goosegrass to (A) maize-cover crop rotation, (B) soil sampling depth, and (C) season in UZ Field A. Data were $\sqrt{ }(x+0.5)$ transformed.

There was no significant $(p>0.05)$ season $*$ depth $*$ maize-cover crop rotation interaction on the density of smooth pigweed in UZ Field A. However, the interactions season * maize-cover crop rotation, depth * maize cover crop rotation and season * depth were significant $(p<0.05)$ (Figure 11). Smooth pigweed density declined significantly in the second season in all rotations except where maize was rotated with common rattlepod and showy rattlebox, as well as the maize monoculture plot (Figure 11A). Significant $(p<0.05)$ variations in smooth pigweed density were observed amongst the different maize-cover crop rotations in the 2014-15 season but not in the 201617 season. In the 2014-15 season, smooth pigweed density was significantly $(p<0.05)$ higher in maize-red Sunn hemp, maize-black Sunn hemp and maize-velvet bean compared to maize-after-maize control. The other maize cover crop rotations did not significantly differ with the maize-after-maize control. A significant $(p<0.05)$ variation in the density of smooth pigweed across the different soil layers was found only in the maize-velvet bean rotation (Figure 11B). In the other maize-cover crop rotations, the density of smooth pigweed did not vary. Smooth pigweed density was significantly $(p<0.05)$ higher at $0-5 \mathrm{~cm}$ depth compared to the other layers in the 2014-15 season (Figure $11 \mathrm{C}$ ). In the 2016-17 season there were no significant differences in the density of smooth pigweed across the three soil layers.
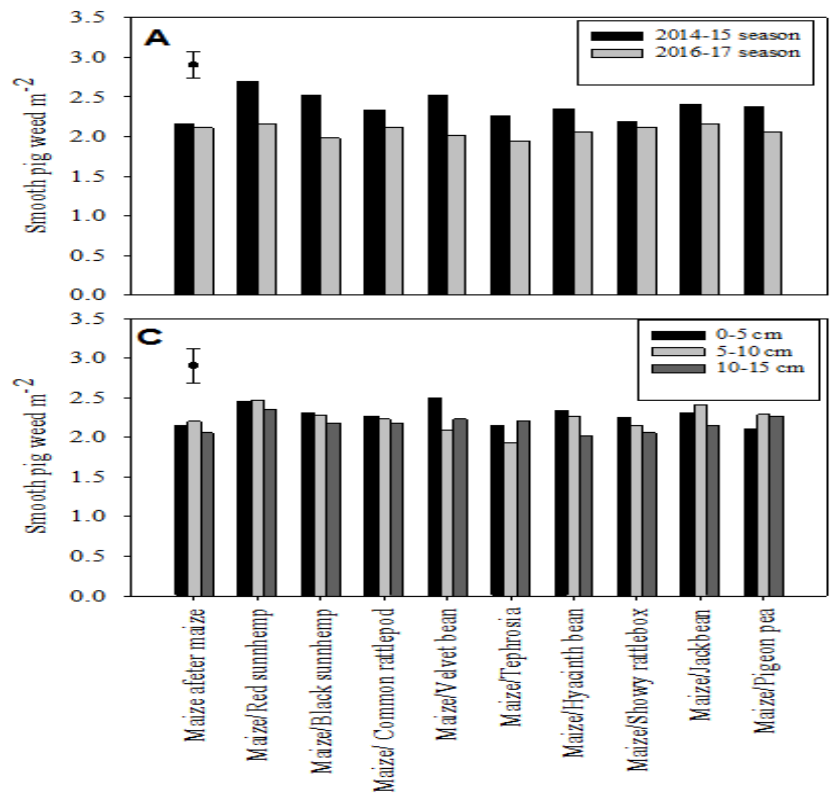

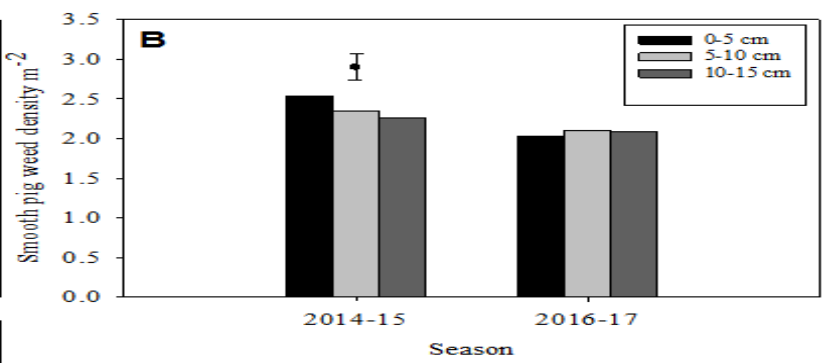

Figure-11. Response of smooth pigweed to (A) maize-cover crop rotation and season, (B) soil sampling depth and season, and (C) maize-cover crop rotation and depth in UZ Field A. Data were $\log _{10}(x)$ transformed. 
Results for the effects of season, depth, and maize-cover crop rotation on the density of gallant soldier at UZ Field A are shown in Figure 12. There was a significant $(p<0.05)$ season $*$ depth * maize-cover crop rotation interaction on the density of gallant soldier. Gallant soldier density was significantly $(p<0.05)$ higher at $0-5 \mathrm{~cm}$ depth compared to the other soil sampling depths in the maize-after-maize control, black Sunn hemp, common rattlepod, velvet bean, and jack bean rotations in the 2014-15 season. However, there were no significant variations in gallant soldier densities across the different maize-cover crop rotations in the 2016-17 season. Gallant solider density significantly $(p<0.05)$ decreased between seasons atin the $0-5 \mathrm{~cm}$ depth where maize was rotated with black Sunn hemp, velvet bean, and jack bean. In contrast, the density of gallant soldier significantly $(p<0.05)$ increased across all sampling depths in the maize-showy rattlebox rotation.

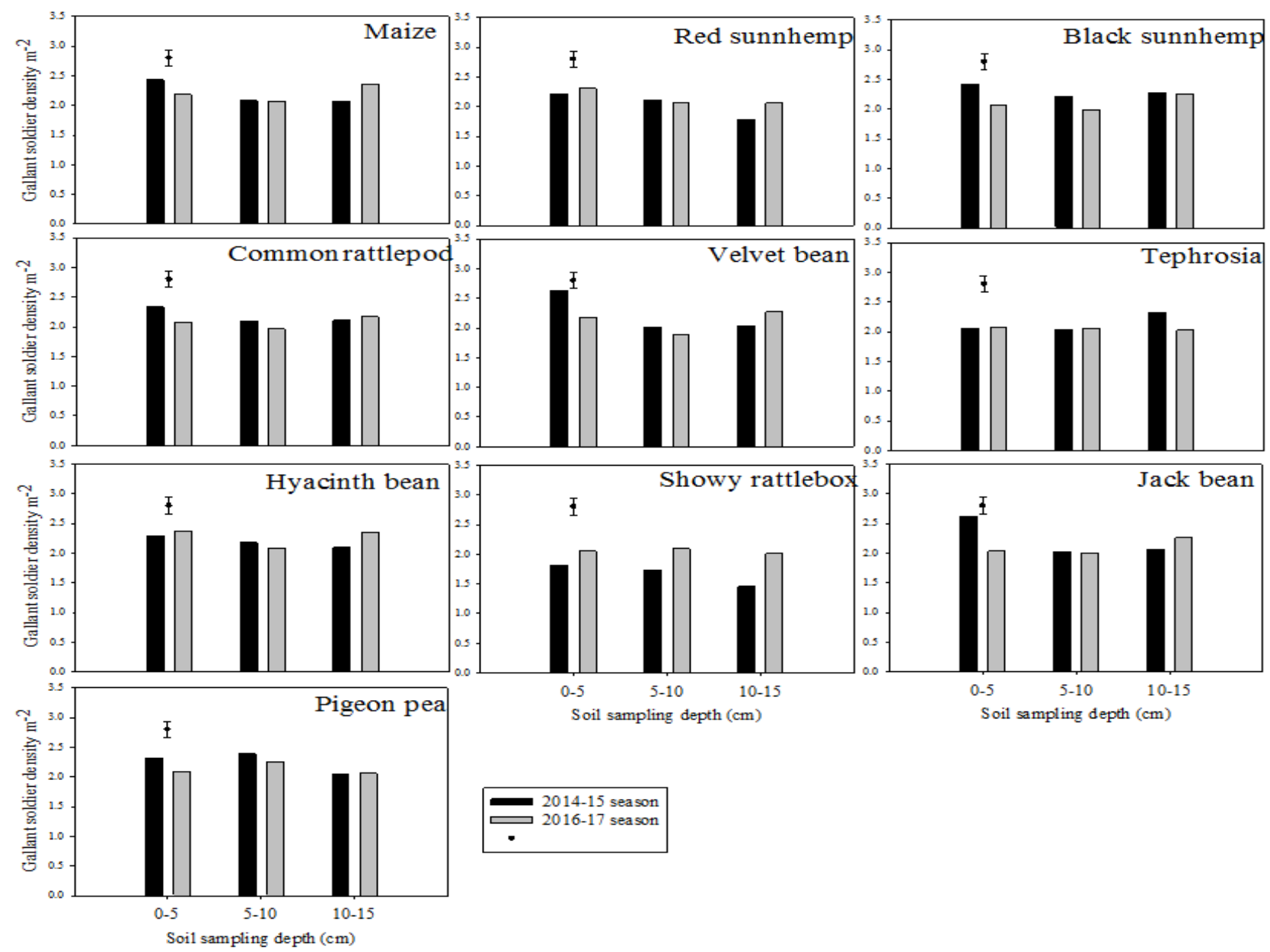

Figure-12. Response of gallant soldier density to different maize-cover crop rotations and soil depths across seasons. Data were log $10(x)$ transformed.

\subsection{Analysis of Weed Density of Major Weeds across Environments and Seasons}

The which-won-where scatter biplots (Figure 13A-D) show the influence of different maize-cover crop rotations on the total density of major weeds across the environments and seasons at $0-15 \mathrm{~cm}$ depth of the seed bank. Blackjack density was highest in the maize-after-maize plots at UZ Field B (2015-16 season) and CIMMYT (201617 season). On the other hand, the density of blackjack was highest in the maize-hyacinth bean and maize-jack bean rotations in the UZ A field in the 2014-15 season. Blackjack density was also high in the maize-black Sunn hemp rotations at both UZ Field A (2014-15) and UZ B (2015-16 season). Smooth pigweed density was high in UZ Field A, in the order red Sunn hemp > black Sunn hemp > hyacinth bean in both the 2014-15 and 2016-17 seasons. The density of smooth pigweed was highest in maize-velvet bean and maize-common rattlepod rotation at CIMMYT. The maize-after-maize control and maize-velvet bean rotation had the highest density of gallant soldier at all UZ fields across all the seasons. At CIMMYT, gallant soldier density was highest in the maize-tephrosia followed by maize-jack bean rotations. Goosegrass density was highest in black Sunn hemp at all UZ fields across seasons. In, contrast, the density of goosegrass was highest in red Sunn hemp and pigeon pea at CIMMYT. 
Total - $94.10 \%$

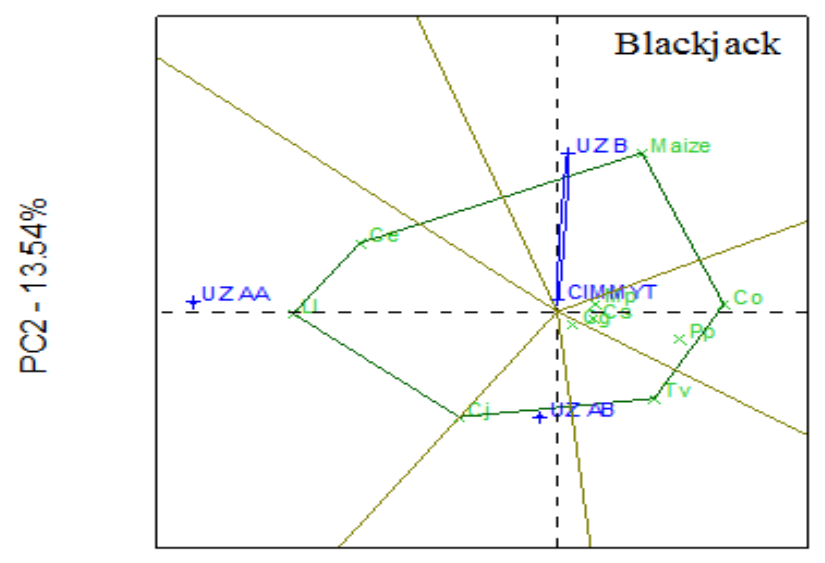

PC1 - 80.56\%

Total - $97.60 \%$

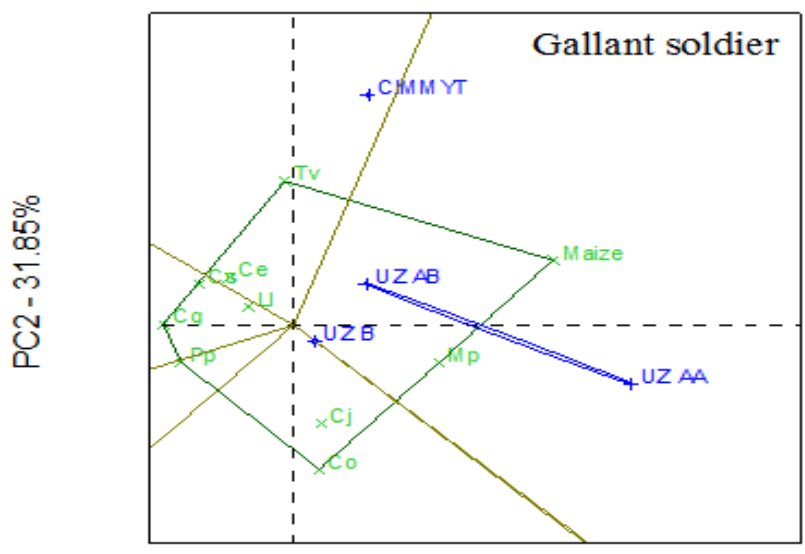

$P C 1-65.74 \%$

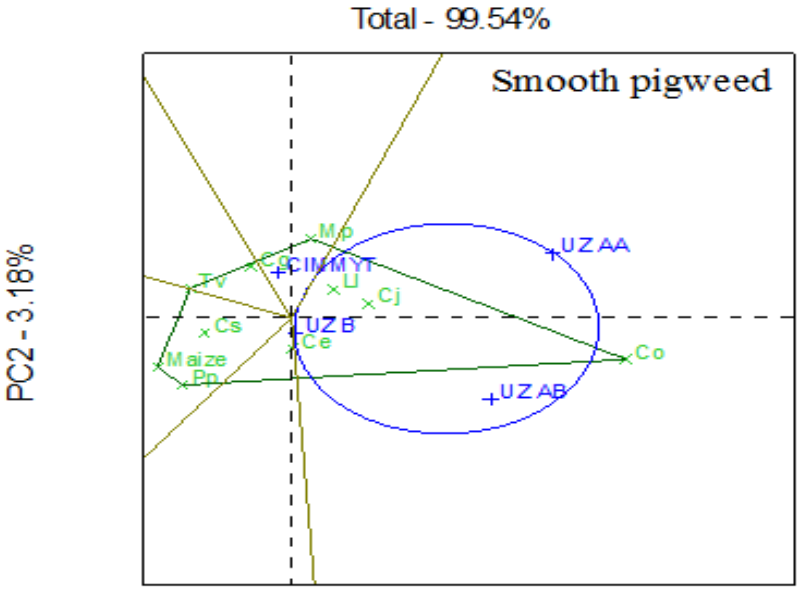

PC1 - 96.37\%

Total - $88.30 \%$

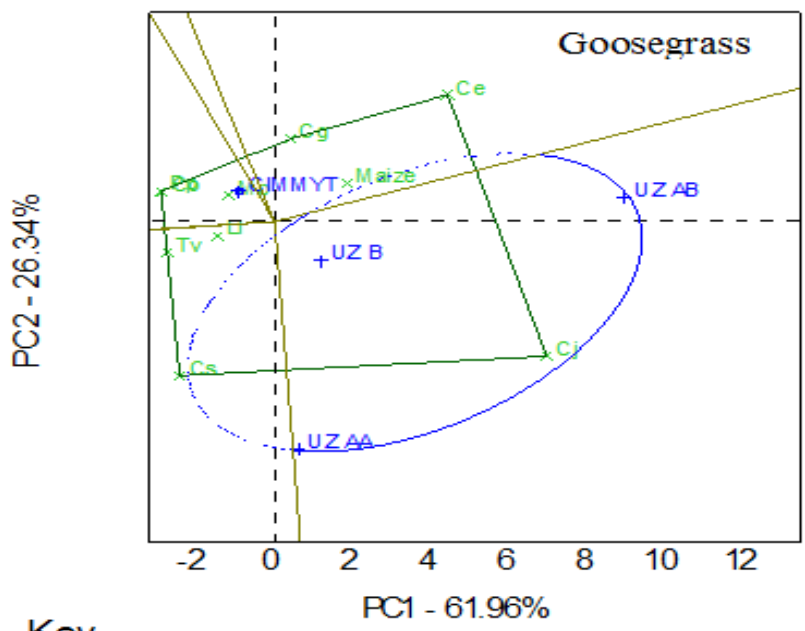

Key

Figure-13. Which-won-where biplot showing the influence of maize-cover crop rotations on the density of blackjack, smooth pigweed, gallant soldier, and goosegrass in different plots across seasons. Co, red Sunn hemp; Cj, black Sunn hemp; Cg, common rattlepod; Mp, velvet bean; Tv, tephrosia; Ll, hyancinth bean; Cs, showy rattlebox; Ce, jack bean; Pp, pigeon pea; UZAA, UZ Field A 2014-15 season; UZ AB, UZ Field A 201617 season); UZ B, UZ Field B 2015-16; CIMMYT 2016-17 season.

\section{DISCUSSION}

The relative densities of weeds that germinated at all sites during the study showed that the seed banks of different fields are dominated by annual weeds, the majority of which broadleaf. The abundance of annual weeds in seed banks could be attributed to the fact that most of the plots were within their first two to three years after shifting from conventional tillage to CA. The only perennial weeds that were present in the $0-15 \mathrm{~cm}$ seed bank were Cyperus spp., probably because they have a dual mode of reproduction and can germinate from seed although their predominant mode of reproduction is through tubers (Botha, 2001). The low numbers of perennial weeds could also be due to the fact that they reproduce vegetatively and the sampling done could have missed vegetative structures such as rhizomes and stolons. The results concur with the findings of Mandumbu et al. (2012), who reported the presence of several annual weeds and only one perennial in seed banks under CA in the early years of adopting reduced tillage. Generally, there were similarities in terms of the types of weed species present in the different seed banks, probably because of similarities in the previous land use, soil types, and climatic conditions of the fields used. Nichols et al. (2015) reported that the initial state of the seed bank influences study results.

Total weed seed density in the plots where maize-cover crop rotations were repeated were lower in the maize phase of the rotation only at $0-5 \mathrm{~cm}$ depth, but did not differ among the different maize-cover crop rotations. The higher weed densities obtained at $0-5 \mathrm{~cm}$ depth compared to the deeper soil layers in this study are consistent with results from other weed seed bank studies (Barberi et al., 2001; Chen et al., 2017; Mandumbu et al., 2012). The higher weed densities found at $0-5 \mathrm{~cm}$ depth could be attributed to the accumulation of weed seeds $(60-90 \%)$ in the top $5 \mathrm{~cm}$ of the soil (Barberi \& Lo Cascio, 2001; Mandumbu et al., 2012). Unlike in conventional tillage, weed seeds penetrate the deeper soil layers through very slow processes like cracking and fauna (Nichols et al., 2015), and hence the differences in seed bank size reported in this study may be due to lack of tillage that distributes weed seeds vertically 
in the soil profile rather than the direct influence of crop rotations. The results concur with the findings of Barberi and Lo Cascio (2001), who reported that weed community composition in the $0-15 \mathrm{~cm}$ layer seemed more influenced by tillage system than by crop rotation.

However, there was a general decline in the density of weed seeds in the seed bank between the seasons in the plots where rotations were repeated (Figure 2). This decline in weed density may be ascribed to the ability of the residues of different cover crops to suppress weed growth and germination, thereby reducing seed rain. Similar findings were reported by Abbas et al. (2018), who found increased decay and reduced seed viability in Phalaris minor in the seed bank after being buried in soil treated with different allelopathic mulches. The maize-velvet bean, maizejack bean, maize-black Sunn hemp, and maize-red Sunn hemp rotations significantly reduced weed density in the $0-5$ cm layer, demonstrating their ability to suppress weed growth under field conditions.

Previous studies conducted under controlled environments identified L-DOPA from velvet bean (Fujii, 1999; Nishihara, Parvez, Araya, Kawashima, \& Fujii, 2005; Soares et al., 2014), phenolics, alkaloids, flavonoids, and phytotoxic polyamines from jack bean (Santos, Moraes, \& Rezende, 2007; Santos, Moraes, \& Rezende, 2010), and delta-hydroxynorleucine (5-hydroxy-2-aminohexanoic acid) from Crotalaria spp. (Adler \& Chase, 2007) as the allelochemicals responsible for weed suppression. The presence of these compounds was also confirmed by Liquid Chromatography Mass Spectrometry (LCMS) (Rugare, 2018). It is possible that the release of these allelochemicals could have resulted in the lower numbers of viable weeds in the second year of rotation. Mechanisms of allelopathic activity include induction of dormancy (Nichols et al., 2015) and enhancement of natural loss of viability of seeds in soil (Anderson, 2005). Moreover, surface accumulation of weed propagules, which happens in CA, exposes seeds of annual weeds to greater risks of mortality through weather variability and predation by both micro- and macrofauna (Nichols et al., 2015). Blubaugh and Kaplan (2015) reported an increase in seed-consuming fauna under reduced tillage compared to conventional tillage, due to either increased habitat (Baraibar, Westerman, Carrión, \& Recasens, 2009) or decreased tillage-induced mortality (Shearim, Reberg-Horton, \& Gallant, 2007). However, these findings contradict the findings of Mtambanengwe et al. (2015) and Barberi and Lo Cascio (2001), who reported that differences in weed species composition were not affected by mulches in the short term. These differences in results could be due to differences in the initial seed bank composition. In this study, the seed bank was dominated by smallseeded weeds which are more susceptible to the effect of allelochemicals, compared to studies in which large-seeded weeds and perennials were more dominant (Liebman \& Davis, 2000; Rueda-Ayala et al., 2015). However, principle component analysis (PCA) of the effect of cover crops in the different environments (fields and seasons) grouped them into the same mega-environment (Figure 5), demonstrating that the changes in weed densities observed could be due to cover crop effects rather than differences in initial weed seed bank composition.

The higher weed seed densities at 10-15 cm depth (Figure 3) in some maize-cover crop rotations in UZ Field B lend credence to the assertion that weed species response to crop rotations in the first years of CA adoption is mainly influenced by previous management practices. The increase in weed density observed in the maize-after-maize plots clearly demonstrates the variable response of weeds to different types of mulch. These results are in agreement with the findings of Mhlanga et al. (2015a), who reported high weed emergence in plots mulched with maize despite the fact that maize has higher mulch biomass weight and percentage ground cover compared to leguminous cover crops. This increase in weed density in plots mulched with maize was also reported by Mtambanengwe et al. (2015), clearly demonstrating that the low weed densities recorded in the cover crop plots were not simply a result of the physical effects of mulching, but may also have been due to the allelochemicals produced as the cover crop residues decomposed. Mulches that are not allelopathic may result in increased weed pressure due to the creation of a soil microclimate that is conducive to weed germination (Mashingaidze, Madakadze, Twomlow, Nyamangara, \& Hove, 2012).

There were variations in the response of blackjack to different maize-cover crop rotations. Blackjack was a dominant weed in two UZ fields, but not at CIMMYT. Very low blackjack numbers recorded at CIMMYT could be attributed to previous high levels of management, because it is an on-station experimental site (Muoni, Rusinamhodzi, \& Thierfelder, 2013). At UZ, management of late-season weeds was poor in preceding seasons and could have resulted in the addition of large quantities of blackjack seed into the seed bank. In both UZ plots, blackjack density was significantly higher in the maize-after-maize plots compared to the other rotations. Similar findings were reported by Mhlanga. et al. (2015b), who found higher weed densities in plots mulched with maize residues. This could imply that this weed is susceptible to allelochemicals produced by cover crops. These results corroborate the work of Runzika, Rugare, and Mabasa (2013), who reported reduced germination and seedling growth of blackjack when treated with aqueous extracts and soil-incorporated biomass of the cover crops used in this study. However, results obtained in this study contrasted with the findings of Mhlanga. et al. (2015b), who reported high blackjack emergence in pigeon pea plots and attributed the high weed number to low biomass production which left the ground bare and allowed for proliferation of weeds.

Goosegrass was the dominant grass species at all sites. This grassy weed produces very small seeds with a high voilure coefficient and is prone to hydrochory and anemochory (Mandumbu. et al., 2012). However, there were no differences in goosegrass density among the different cover-crop rotations and across soil layers, probably due to age of the rotation, which was too short to have resulted in significant changes in weed density as a result of treatment effects.

Smooth pigweed densities decreased in the second season, with most seeds being found at $0-5 \mathrm{~cm}$ depth, although density was influenced by neither soil sampling depth nor maize-cover crop rotation type, except in the maize-after-maize and maize-showy rattlebox rotations where it did not significantly change. These findings suggest that this weed is susceptible to different allelochemicals produced by cover crops, hence the higher densities in maize 
residues which are generally not allelopathic. Showy rattlebox establishes slowly, produces little biomass, and does not achieve complete ground cover. As a result it leaves a lot of gaps in the field which allow penetration of light and heat, resulting in high soil temperatures that are conducive for the proliferation of smooth pigweed (Damalas, 2008).

Gallant soldier was present in high numbers at all sites, accounting for more than $20 \%$ of total weed density at all sites probably due to the fact that it is a cosmopolitan weed that can survive in different habitats (Botha, 2001). The which-won-where biplot showed higher densities of gallant soldier in maize-after-maize plots in UZ fields compared to the other maize-cover crop rotations, further lending credence to the assertion that it could have been affected by allelochemicals that were produced by cover crops as they decomposed. Several allelopathic compounds have been previously isolated from some of the cover crops used in this study. It is possible that these allelochemicals released by cover crop residues could have played a role in suppressing weed growth and reducing the subsequent addition of more weed seeds into the non-aerial seed bank.

Mexican clover was a primary weed found only at CIMMYT, but its density was affected by neither sampling depth nor maize-cover crop rotation. This weed is an acidophile that tends to dominate in light-textured soils with very low pH and fertility. These results concur with those of Mhlanga et al. (2015b), who reported high Mexican clover numbers in maize-after-maize plots. However, they reported low numbers of Mexican clover in maize-velvet bean rotation, contrary to results of this study which showed high Mexican clover densities in velvet bean.

The number of weed species (species richness) present in the seed bank did not vary among maize-cover crop rotations in either season in UZ Field A. The lack of substantial variation in species richness in short-term rotations was previously reported by Barberi and Lo Cascio (2001), who attributed this to the buffering effect of weed seed banks. This result implies that short-term rotations may not be a way to rapidly reduce the number of troublesome weeds in arable fields. The significantly higher species richness in the $0-5 \mathrm{~cm}$ soil layer could be due to the deposition of weed propagules in these layers arising from several dispersal agents, which did not happen in the $5-15 \mathrm{~cm}$ layer. These findings are in agreement with the results of Chen et al. (2017), who reported significantly higher weed species richness at $0-5 \mathrm{~cm}$ depth. A similar trend was observed for species evenness, which is a measure of how evenly weeds are distributed in an environment (Nolan \& Callahan, 2006). Weed species evenness ranged from 0.27 to 0.41, showing that there were dominant weeds in this plot. The lower species evenness values in the second season (201617) compared to the first (2014-15) in the rotation at UZ show the emergence of dominant species in the rotations. This could imply that cover crops are effective at suppressing growth of some weeds but not all. The dominant weeds that remain can be controlled by spot weeding or the application of herbicides, thereby reducing the cost of weed control (Muoni et al., 2014). Consequently, there were significant variations in species diversity. Species diversity decreased in the 2016-17 season in UZ Field A, indicating the ability of cover crop mulches to suppress some weed species. Similar findings were reported by Jones, Jessop, Sindel, and Hoult (1999) and Mtambanengwe et al. (2015), who found low diversity where mulching and timeous weeding were combined. However, no clear trends were obtained in the first season of rotations, indicating that changes in weed community composition occur after at least one rotation.

\section{CONCLUSION}

The results of this study illustrate the short-term benefits of maize-cover crop rotations on total weed density. The results also show that mulching with cover crop residues reduces seed bank size better than maize residues, and this change in weed populations may be attributed to the release of allelochemicals and alteration of the soil microenvironment. Cover crops were effective in reducing the density of blackjack but not the other broadleaf weeds, suggesting that the effect of the weed suppression activity of cover crops could be weed species specific. However, no clear trends on weed species composition were established due to short-term maize cover crop rotations. Therefore, there could be merit in practicing crop rotation for several seasons in order to realize the changes in weed species composition reported by other researchers. The effect of the different cover crops in reducing weed seed bank size was similar, and therefore the choice of cover crop would depend on other factors and not simply their ability to control weeds, because they all demonstrated potential to reduce weed seed bank size. There is a need for this study to be replicated in several agroecological regions under farmer-managed conditions, to determine the effect of maize cover crop rotation on weeds in different soil types with different initial weed species composition, including perennial and parasitic weeds.

Funding: Support for this research was made possible through a capacity-building competitive grant training the next generation of scientists, provided by the Carnegie Cooperation of New York through the Regional Universities Forum for Capacity Building in Agriculture (RUFORUM).

Competing Interests: The authors declare that they have no competing interests.

Contributors/Acknowledgement: All authors contributed equally to the conception and design of the study.

Views and opinions expressed in this study are those of the authors views; the Asian Journal of Agriculture and Rural Development shall not be responsible or answerable for any loss, damage, or liability, etc. caused in relation to/arising out of the use of the content. 


\section{REFERENCES}

Abbas, T., Nadeem, M. A., Tanveer, A., Ali, H. H., \& Farooq, N. (2018). Role of allelopathic crop mulches and reduced doses of tank-mixed herbicides in managing herbicide-resistant Phalaris minor in wheat. Crop Protection, 110, 245-250.Available at: https://doi.org/10.1016/j.cropro.2017.06.012.

Adler, M. J., \& Chase, C. A. (2007). Comparison of the allelopathic potential of leguminous summer cover crops: Cowpea, sunn hemp, and velvetbean. HortScience, 42(2), 289-293.

Anderson, R. L. (2005). A multi-tactic approach to manage weed population dynamics in crop rotations. Agronomy Journal, 97(6), 1579-1583.Available at: https://doi.org/10.2134/agronj2005.0194.

Baraibar, B., Westerman, P. R., Carrión, E., \& Recasens, J. (2009). Effects of tillage and irrigation in cereal fields on weed seed removal by seed predators. Journal of Applied Ecology, 46(2), 380-387.

Barberi, P., Bonari, E., \& Mazzoncini, M. (2001). Weed density and composition in the winter wheat as influenced by tillage systems. In: Garcia-Torres and Martinez Vilela (eds). 1 World Congress on Conservation Agriculture (Vol. 11). Madrid: FAO and ECAF.

Barberi, P., \& Lo Cascio, B. (2001). Long-term tillage and crop rotation effects on weed seedbank size and composition. Weed Research, 41(4), 325-340.

Bezuidenhout, S. R., Reinhardt, C. F., \& Whitwell, M. I. (2012). Cover crops of oats, stooling rye and three annual ryegrass cultivars influence maize and Cyperus esculentus growth. Weed Research, 52(2), 153-160.

Blubaugh, C. K., \& Kaplan, I. (2015). Tillage compromises weed seed predator activity across developmental stages. Biological Control, 81, 76-82.

Botha, C. (2001). Common weeds of crops and gardens in southern Africa. Potchefstroom, South Africa: ARC-Grain Crops InstituteLNR-Instituut vir Graangewasse.

Chen, G., Liu, Q., Zhang, Y., Li, J., \& Dong, L. (2017). Comparison of weed seed banks in different rice planting systems. Agronomy Journal, 109(2), 620-628.

Chitagu, M. R., Rugare, J. T., \& Mabasa, S. (2014). Screening maize (Zea mays) genotypes for tolerance to witchweed [Striga asiatica (L.) Kuntze] infection. Journal of Agricultural Science, 6(2), 1-10.

Damalas, C. A. (2008). Distribution, biology, and agricultural importance of Galinsoga parviflora (Asteraceae). Weed Biology and Management, 8(3), 147-153.

Forcella, F., Willson, R. G., Dekker, J., Kremer, R. J., Cardina, J., Anderson, R. L., . . Buhler, D. G. (1997). Weed seed bank emergence across the Corn Belt. Weed Science, 45(1), 67-76.Available at: https://doi.org/10.1017/s0043174500092493.

Fujii, Y. T. (1999). Allelopathy of Hairy Vetch and Mucuna: Their applications for sustainable agriculture. In: Chou CH, Waller GR, Reinhardt C. (eds). Biodiversity and allelopathy from organisms to ecosystems in the pacific (pp. 289-300). Taipei: Academia Sinica.

Genstat. (2011). Genstat 14 reference manual: Release. Oxford, UK: Clarendon Press.

Gomez, K. A., \& Gomez, A. A. (1984). Statistical procedures for agricultural research. New York: John Wiley \& Sons.

Hossain, M. M., \& Begum, M. (2015). Soil weed seed bank: Importance and management for sustainable crop production-A review. Journal of the Bangladesh Agricultural University, 13(2), 22 1-228.

Jones, E., Jessop, R., Sindel, B., \& Hoult, A. (1999). Utilising crop residues to control weeds. School of Rural Science and Natural Resources. Armidale: University of New England.

Khan, Z. R., Pickett, J. A., Wadhams, L. J., Hassanali, A., \& Midega, C. A. (2006). Combined control of Striga hermonthica and stemborers by maize-Desmodium spp. intercrops. Crop Protection, 25(9), 989-995.

Liebman, M., \& Davis, A. (2000). Integration of soil, crop and weed management in low-external-input farming systems. Weed Research, $40(1), 27-48$.

Little, T. M., \& Hills, F. J. (1978). Agricultural experimentation (pp. 350). New York, USA: John Wiley and Sons.

Mandumbu, R., Musvosvi, C., \& Rugare, J. T. (2010). Methods and applications of weed seed banks in weed management: A review. Midlands State University Journal of Science and Technology, 2, 55-64.

Mandumbu, R., Twomlow, S. J., Jowah, P., Mashingaidze, N., Hove, L., \& Karavina, C. (2012). Weed seed bank response to tillage and residue management in semi-arid Zimbabwe. Archives of Phytopathology and Plant Protection, 45(18), $2165-2176$.

Mashingaidze, N., Madakadze, C., Twomlow, S., Nyamangara, J., \& Hove, L. (2012). Crop yield and weed growth under conservation agriculture in semi-arid Zimbabwe. Soil and Tillage Research, 124, 102-110.

Mhlanga, B., Cheesman, S., Maasdorp, B., Mupangwa, W., \& Thierfelder, C. (2015a). Contribution of cover crops to the productivity of Maize-Based conservation agriculture systems in Zimbabwe. Crop Science, 55(4), 1791-1805.

Mhlanga, B., Cheesman, S., Maasdorp, B., Muoni, T., Mabasa, S., Mangosho, E., \& Thierfelder, C. (2015b). Weed community responses to rotations with cover crops in maize-based conservation agriculture systems of Zimbabwe. Crop Protection, 69, 1-8.Available at: https://doi.org/10.1016/j.cropro.2014.11.010.

Mhlanga, B., Cheesman, S., Chauhan, B. S., \& Thierfelder, C. (2016). Weed emergence as affected by maize (Zea mays L.)-cover crop rotations in contrasting arable soils of Zimbabwe under conservation agriculture. Crop Protection, 81(March), 47-56.

Mickelson, J. A., \& Grey, W. E. (2006). Effect of soil water content on wild oat (Avena fatua L.) seed mortality and seedling emergence. Weed Science, 54(2), 255-262.Available at: https://doi.org/10.1614/ws-05-007r.1.

Morris, J. B., Chase, C., Treadwell, D., Koenig, R., Cho, A., Morales-Payan, J. P., \& Antonious, G. F. (2015). Effect of sunn hemp (Crotalaria juncea L.) cutting date and planting density on weed suppression in Georgia, USA. Journal of Environmental Science and Health, Part B, 50(8), 614-621.

Mtambanengwe, F., Nezomba, H., Tauro, T., Chagumaira, C., Manzeke, M. G., \& Mapfumo, P. (2015). Mulching and fertilization effects on weed dynamics under conservation agriculture-based maize cropping in Zimbabwe. Environments, 2(3), 399414 .

Muoni, T., Rusinamhodzi, L., \& Thierfelder, C. (2013). Weed control in conservation agriculture systems of Zimbabwe: Identifying economical best strategies. Crop Protection, 53, 23-28.Available at: https://doi.org/10.1016/j.cropro.2013.06.002.

Muoni, T., Rusinamhodzi, L., Rugare, J. T., Mabasa, S., Mangosho, E., Mupangwa, W., \& Thierfelder, C. (2014). Effect of herbicide application on weed flora under conservation agriculture in Zimbabwe. Crop Protection, 66, 1-7.Available at: https://doi.org/10.1016/j.cropro.2014.08.008.

Muoni.., T., \& Mhlanga, B. (2014). Weed management in Zimbabwean smallholder conservation agriculture farming sector. Asian Journal of Agriculture and Rural Development, 4(393-2016-23782), 267-276. 
Nichols, V., Verhulst, N., Cox, R., \& Govaerts, B. (2015). Weed dynamics and conservation agriculture principles: A review. Field Crops Research, 183, 56-68.Available at: https://doi.org/10.1016/j.cropro.2013.06.002.

Nishihara, E., Parvez, M. M., Araya, H., Kawashima, S., \& Fujii, Y. (2005). L-3-(3, 4-Dihydroxyphenyl) alanine (L-DOPA), an allelochemical exuded from velvetbean (Mucuna pruriens) roots. Plant growth regulation, 45(2), 113-120.

Nolan, K. A., \& Callahan, J. E. (2006). Beachcomber biology: The Shannon-Weiner Species Diversity Index. In O'Donnell MA (ed) Tested Studies for Laboratory Teaching. Paper presented at the Proceedings of the 27th Workshop/Conference of the Association for Biology Laboratory Education (ABLE).

Nyamapfene, K. W. (1999). The Soils of Zimbabwe. Harare, Zimbabwe: Nehanda Publishers (Pvt) Ltd.

Reinhardt, C. F., \& Terfamichael, N. (2011). Nitrogen in combination with Desmodium intortum effectively suppress Striga asiatica in a sorghum-Desmodium intercropping system. Journal of Agriculture and Rural Development in the Tropics and Subtropics, 112(1), 19-28.

Rueda-Ayala, V., Jaeck, O., \& Gerhards, R. (2015). Investigation of biochemical and competitive effects of cover crops on crops and weeds. Crop Protection, 71 (May), 79-87.

Rugare, J. T. (2018). Allelopathic effects of green manure cover crops on the germination and growth of blackjack (Bidens pilosa L.) and goosegrass grass [Eleusine indica (L.) Gaertn]. PhD Thesis, Stellenbosch University, South Africa.

Runzika, M., Rugare, J., \& Mabasa, S. (2013). Screening green manure cover crops for their allelopathic effects on some important weeds found in Zimbabwe. Asian Journal of Agriculture and Rural Development, 3(393-2016-23816), 554-565.

Santos, S., Moraes, M., \& Rezende, M. (2007). Allelopathic potential and systematic evaluation of secondary compounds in extracts from roots of Canavalia ensiformis by capillary electrophoresis. Eclética Química, 32(4), 13-18.

Santos, S., Moraes, M., \& Rezende, M. (2010). Determination of polyamines in organic extracts from roots of Canavalia ensiformis by capillary electrophoresis. Journal of Environmental Science and Health Part B, 45(4), 325-329.

Shearim, A., Reberg-Horton, S., \& Gallant, E. (2007). Direct effects of tillage on the activity density of ground beetle (Coleoptera: Carabidae) weed seed predators. Environmental Entomology, 36(5), 1140-1 146.

Singh, A., Kaur, R., Kang, J., \& Singh, G. (2012). Weed dynamics in rice-wheat cropping system. Global Journal of Biology Agriculture and Health Sciences, 1, 7-16.

Soares, A. R., Marchiosi, R., Siqueira-Soares, R. d. C., Barbosa de Lima, R., Dantas dos Santos, W., \& Ferrarese-Filho, O. (2014). The role of L-DOPA in plants. Plant Signaling \& Behavior, 9(4), e28275.

White, S. S., Renner, K. A., Menalled, F. D., \& Landis, D. A. (2007). Feeding preferences of weed seed predators and effect on weed emergence. Weed Science, 55(6), 606-612.

Yan, W., Hunt, L., Sheng, Q., \& Szlavnics, Z. (2000). Cultivar evaluation and mega-environment investigation based on the GGE biplot. Crop Science, 40(3), 597-605.

Yan, W., \& Kang, M. S. (2002). GGE biplot analysis: A graphical tool for breeders, geneticists, and agronomists. Florida, United States of America: CRC Press. 